\title{
Influence of irradiance and iron on the growth of colonial Phaeocystis antarctica: implications for seasonal bloom dynamics in the Ross Sea, Antarctica
}

\author{
Nathan S. Garcia ${ }^{1,3, *}$, Peter N. Sedwick ${ }^{2}$, Giacomo R. DiTullio ${ }^{1}$ \\ ${ }^{1}$ College of Charleston, 331 Fort Johnson Road, Charleston, South Carolina 29412, USA \\ ${ }^{2}$ Department of Ocean, Earth and Atmospheric Sciences, Old Dominion University, 4600 Elkhorn Avenue, Norfolk, \\ Virginia 23529, USA \\ ${ }^{3}$ Present address: University of Southern California, 3616 Trousdale Parkway, Los Angeles, California 90089, USA
}

\begin{abstract}
Laboratory culture experiments were used to investigate the growth rate of colonial Phaeocystis antarctica as a function of irradiance and dissolved iron concentration. The experiments were conducted with a P. antarctica strain isolated from the southern Ross Sea, Antarctica, and made use of natural, low-iron ( $<0.2 \mathrm{nM}$ dissolved Fe) filtered seawater as a growth medium, thereby avoiding the addition of synthetic organic ligands to regulate dissolved iron concentrations. Under ironand nutrient-replete conditions, colonial $P$. antarctica attained an average maximum cell-specific growth rate of $0.37 \mathrm{~d}^{-1}$ at an irradiance of $68 \mu \mathrm{E} \mathrm{m} \mathrm{m}^{-2} \mathrm{~s}^{-1}$, above which growth rates decreased to $0.27 \mathrm{~d}^{-1}$ at an irradiance of $314 \mu \mathrm{E} \mathrm{m}^{-2} \mathrm{~s}^{-1}$. The dependence of growth rate on ambient dissolved iron concentration was examined in dose-response type bioassay experiments using realistic subnanomolar additions of dissolved iron. The experimental results indicate significant changes in the iron requirements for growth of colonial $P$. antarctica as a function of irradiance, with our estimates of the half-saturation constant for growth with respect to dissolved iron $\left(K_{\mu}\right)$ ranging from $0.26 \mathrm{nM}$ at $\sim 20 \mu \mathrm{E} \mathrm{m}^{-2} \mathrm{~s}^{-1}$, to $0.045 \mathrm{nM}$ at $\sim 40 \mu \mathrm{E} \mathrm{m}^{-2} \mathrm{~s}^{-1}$ and to $0.19 \mathrm{nM}$ at $\sim 90 \mu \mathrm{E} \mathrm{m}^{-2} \mathrm{~s}^{-1}$. We interpret these variations in $K_{\mu}$ as reflecting an increase in the cellular iron requirements of colonial $P$. antarctica at suboptimal and supraoptimal irradiance, such that the cells require higher ambient dissolved iron concentrations to attain maximum growth rates under such irradiance conditions. The experiments also provide evidence of a relationship between iron availability and the relative proportion of colonial versus solitary $P$. antarctica cells, whereby the colonial form appears to be favored by higher dissolved iron concentrations. Our experimental results suggest that the initiation and termination of colonial $P$. antarctica blooms in the Ross Sea are determined by the combined effects of irradiancedriven changes in cellular iron requirements and a seasonal decrease in dissolved iron availability.
\end{abstract}

KEY WORDS: Phaeocystis antarctica $\cdot$ Growth $\cdot$ Iron $\cdot$ Light $\cdot$ Ross Sea $\cdot$ Bloom dynamics

\section{INTRODUCTION}

The largest and most predictable phytoplankton blooms in the Southern Ocean are observed over the Antarctic continental shelves, particularly in the southern Ross Sea (Smith \& Gordon 1997, Arrigo et al. 1998a, Arrigo \& van Dijken 2003). Here the phytoplankton community is typically dominated by blooms of colonial Phaeocystis antarctica in austral spring and early summer (October to December), followed by diatom blooms in mid- to late summer (Bunt \& Wood 1963, El-Sayed et al. 1983, Comiso et al. 1993, DiTullio \& Smith 1996, Smith \& Gordon 1997, Arrigo et al. 1998b, Goffart et al. 2000, Smith et al. 2000, Arrigo \& van Dijken 2004). P. antarctica is considered a keystone species in this region, because of its major role in the biogeochemical cycling of carbon, sulfur and nutrient elements (Gibson et al. 1990, Smith et al. 1991, 
DiTullio \& Smith 1995, Arrigo et al. 1999, DiTullio et al. 2000, Sweeney et al. 2000, Schoemann et al. 2005). The factors that control the spatial and temporal distribution of $P$. antarctica blooms in the southern Ross Sea are not well understood. Bottom-up controls by irradiance, iron and vitamin $B_{12}$ have been suggested (Arrigo et al. 1998b, Fitzwater et al. 2000, Sedwick et al. 2000, Smith et al. 2003a, Bertrand et al. 2007), whereas top-down control by grazing pressure is not thought to be significant (Caron et al. 2000, Tagliabue \& Arrigo 2003). Field observations document a general decrease in the depth of the surface mixed layer, which allows an increase in mean irradiance during the growing season (Arrigo et al. 1998b, Gordon et al. 2000, Smith et al. 2003a, Sweeney 2003, Worthen \& Arrigo 2003). Over the same period, the concentrations of dissolved iron in the surface mixed layer apparently decrease from $\sim 0.2-0.5 \mathrm{nM}$ or more to $<0.2 \mathrm{nM}$, while dissolved macronutrient concentrations remain relatively high (Fitzwater et al. 2000, Sedwick et al. 2000, Smith et al. 2003a, Coale et al. 2005).

Studies of the effects of light on the growth of Phaeocystis antarctica suggest that this species is inherently well adapted to low and/or highly variable irradiance (Palmisano et al. 1986, Arrigo et al. 1999, van Leeuwe \& Stefels 2007). On this basis, it has been argued that the ability of $P$. antarctica to maintain high rates of photosynthesis at low or variable irradiance allows this species to dominate the poorly stratified waters of the southern Ross Sea during spring (Leventer \& Dunbar 1996, Arrigo et al. 1998b, 1999, Goffart et al. 2000). This hypothesis can explain the observed spatial and temporal separation of $P$. antarctica and diatom blooms in the Ross Sea, if it is assumed that diatoms are better adapted to the stable higher irradiance of more stratified waters (Arrigo et al. 1998b, 1999, 2003, Sedwick et al. 2000). However, this idea is challenged by the results of field and laboratory studies that indicate little difference between the photosynthesisirradiance characteristics of $P$. antarctica and diatoms in the southern Ross Sea (van Hilst \& Smith 2002, Smith \& van Hilst 2004).

Availability of iron is also likely to influence the timing and location of Phaeocystis antarctica and diatom blooms in the Ross Sea. Certainly there is good evidence for the role of iron availability in limiting phytoplankton growth rates in this region, as shown in the results of shipboard bioassay experiments (Martin et al. 1990, Sedwick \& DiTullio 1997, Sedwick et al. 2000, Coale et al. 2003). This and the antagonistic relationship between the iron requirements of phytoplankton and irradiance, whereby phytoplankton require more iron per cell under sub-optimal irradiance (Raven 1990, Sunda \& Huntsman 1997, van Leeuwe \& Stefels 2007), lead to the hypothesis that both iron availability and irradiance exert controls on the distribution and species composition of phytoplankton blooms in the Ross Sea (Sedwick et al. 2000, 2007, Boyd 2002, Arrigo et al. 2003). Indeed, recent numerical models of the Ross Sea ecosystem (Arrigo et al. 2003, Arrigo \& Tagliabue 2005, Tagliabue \& Arrigo 2005) have successfully simulated the broad, regional-scale features of $P$. antarctica and diatom blooms by incorporating explicit limitation of growth rates by iron availability and vertical mixing (i.e. irradiance). These models prescribe an elevated growth rate for $P$. antarctica at low irradiance, and for diatoms at high irradiance, with an additional constraint of photoinhibition for $P$. antarctica at high light (Arrigo et al. 2003). The models also assume a significantly higher iron requirement for the growth of diatoms relative to colonial $P$. antarctica, by prescribing a higher Fe/C uptake ratio and higher half-saturation constant for growth with respect to iron $\left(K_{\mu}\right)$ for diatoms (Tagliabue \& Arrigo 2005). The resulting model simulations imply that iron availability controls annual primary production, whereas the differential responses of $P$. antarctica and diatoms to variable light regimes control the distribution of these algal groups in space and time.

However, the broad-scale agreement of model simulations with field observations does not necessarily imply that such models are mechanistically accurate. At present, there is considerable uncertainty regarding the phytoplankton iron parameters used in such models, and the use of fixed values for these parameters may be inappropriate (Tagliabue \& Arrigo 2005).

In this context, there is a pressing need for quantitative information concerning the iron requirements for growth of colonial Phaeocystis antarctica; that is, the growth rate of colonial $P$. antarctica as a function of ambient dissolved iron concentration. Quantitatively, this information is provided by $K_{\mu}$, which represents the ambient dissolved iron concentration at which phytoplankton achieve a growth rate $(\mu)$ that is $50 \%$ of the maximum iron-saturated growth rate $\left(\mu_{\max }\right)$ for a given irradiance under nutrient replete conditions (e.g. see Timmermans et al. 2001, 2004). Coale et al. (2003) performed shipboard dose-response iron-addition experiments in the Ross Sea and observed an increase in the abundance of haptophytes (presumably $P$. antarctica) in response to iron addition, with their results suggesting relatively low $K_{\mu}$ values in the range of 0.005 to $0.043 \mathrm{nM}$ dissolved iron. However, these experiments were conducted under full sea-surface irradiance during late summer when there is an increased abundance of solitary $P$. antarctica cells (Smith et al. 2003b); hence, the experimental results might not be representative of the colonial $P$. antarctica blooms that dominate the southern Ross Sea in spring and early summer. 
In this paper, we report the results of laboratory experiments that examined the growth of predominantly colonial Phaeocystis antarctica cultures as a function of both irradiance and dissolved iron concentration. For these experiments we used a recent isolate of $P$. antarctica and filtered low-iron seawater, both collected from the southern Ross Sea, in an effort to simulate natural field conditions. Our results indicate that the iron requirements for growth of colonial $P$. antarctica (as expressed by $K_{\mu}$ ) vary significantly as a function of irradiance and suggest a new conceptual model for the role of iron availability and irradiance in regulating the growth of $P$. antarctica in the Ross Sea.

\section{MATERIALS AND METHODS}

To glean meaningful data from laboratory studies of marine phytoplankton, the experimental conditions should approach natural field conditions as closely as possible. This includes not only the physical and chemical conditions of the experiments, but also the culture history of the phytoplankton that are used. Ideally, the algae used should be recent field isolates, rather than laboratory clones that have been cultured over extended periods of time under temperature, irradiance and nutrient conditions that are different from the natural environment. Over a period of years, such conditions might be expected to result in significant gene mutations and/or deletions in the cultured algal strains relative to phytoplankton in the field. In the present study, we conducted experiments with a field isolate of Phaeocystis antarctica that was cultured in our laboratory over a period of approximately $2 \mathrm{yr}$, and used natural, low-iron, surface seawater from the Ross Sea as a basic growth medium.

Field collections and culture isolation. A unialgal strain of Phaeocystis antarctica was isolated from mixed algal assemblages collected in the southern Ross Sea during December 2003. These assemblages were collected near $76^{\circ} 05^{\prime} \mathrm{S}, 170^{\circ} 08^{\prime} \mathrm{E}$ (Fig. 1) in Niskin bottles mounted on a CTD rosette deployed from the research vessel 'Nathaniel B. Palmer' (cruise NBP03-05A). The algal assemblages were maintained in L1 nutrient medium (Guillard \& Hargraves 1993) diluted 20-fold with filtered surface seawater (hereafter $\mathrm{L} 1 / 20$ medium), at $0^{\circ} \mathrm{C}$ in a shipboard Percival incubator. After the cruise, the algal cultures were transported to the Hollings Marine Laboratory in Charleston, South Carolina, where $P$. antarctica colonies were isolated using a capillary pipette, then transferred through a series of 5 or more glass wells containing L1/20 medium. Several unialgal cultures of $P$. antarctica were grown from these isolated colonies in $\mathrm{L} 1 / 20$ medium at $0^{\circ} \mathrm{C}$. The colonial form dominated

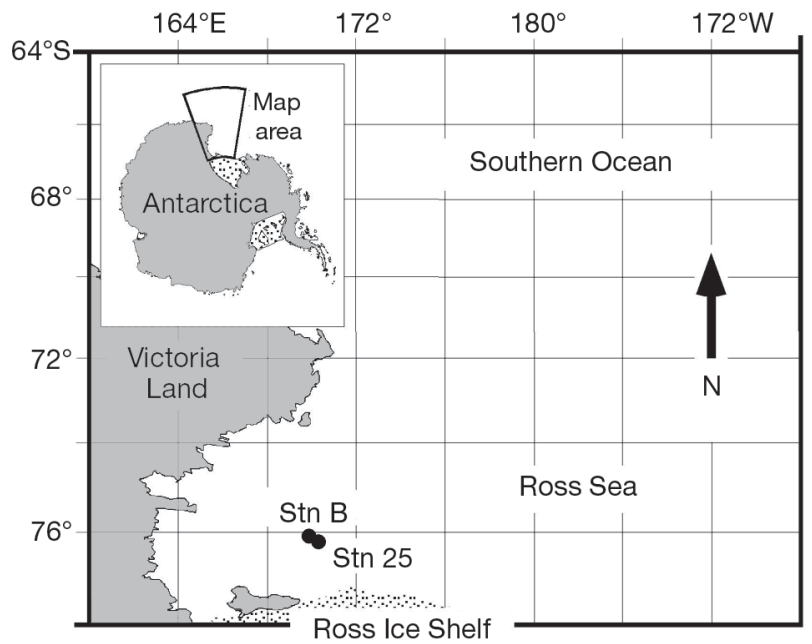

Fig. 1. The Ross Sea indicating collection locations for lowiron filtered seawater (Stn B) and phytoplankton (Stn 25) used in this study

cultures, and the absence of other phytoplankton species was verified by microscopy. One of these $P$. antarctica cultures, NBP03-05A-25, was the primary source culture for all experiments described in this report.

All growth media used for maintaining cultures and conducting laboratory experiments were prepared with low-iron filtered seawater collected from the southern Ross Sea near $76^{\circ} 02^{\prime} \mathrm{S}, 1^{\circ} 9^{\circ} 53^{\prime} \mathrm{E}$ (Fig. 1) in December 2003. Approximately 40001 of this low-iron seawater was collected from $\sim 10 \mathrm{~m}$ water depth through acid-cleaned polyethylene tubing, which was deployed on a non-metal line from the research vessel 'Nathaniel B. Palmer' while slowly underway. The seawater was pumped aboard using an electrically operated polypropylene-Santoprene double-diaphragm pump (Jabsco), filtered through in-line, acid-rinsed $1-\mu \mathrm{m} / 0.2-\mu \mathrm{m}$ pleated-polypropylene cartridge filters with a $1 \mu \mathrm{m}$ prefilter (Cole-Parmer), and collected in acid-cleaned 1251 opaque polyethylene barrels with air-tight polyethylene screw closures. Subsequent measurements of iron in sub-samples of this filtered seawater (Sedwick et al. 2007) revealed relatively low dissolved iron $(\mathrm{dFe})$ concentrations of $0.07 \pm 0.02 \mathrm{nM}$ (mean $\pm 1 \mathrm{SD}, \mathrm{n}=4$ ). This seawater is hereafter referred to as filtered low-iron seawater. For use in the experiments described in this paper, the seawater was removed from the polyethylene barrels through acidcleaned silicone tubing using a peristaltic pump, with in-line filtration through a pre-rinsed $0.2 \mu \mathrm{m}$ Supor CritiCap filter capsule (Pall), following a stringent trace-metal clean transfer protocol.

Laboratory irradiance experiments. Batch-culture incubation experiments were performed to examine 
Table 1. Summary of data from light experiments with Phaeocystis antarctica. See details in 'Materials and methods' and 'Results'. Data in bold text are plotted in Fig. 3

\begin{tabular}{|c|c|c|c|c|c|c|c|c|c|c|}
\hline \multicolumn{6}{|c|}{$\begin{array}{c}\text { Light experiment } \\
\text { Irradiance treatment cell density }\left(\text { cells } \mathrm{ml}^{-1}\right) \\
\text { at sampling time points from } 0 \text { to } 39 \mathrm{~d}\end{array}$} & \multicolumn{5}{|c|}{$\begin{array}{l}\text { Growth period }\left(t_{\mathrm{d}}\right) \\
\text { Growth rate }\left(\mathrm{d}^{-1}\right)\end{array}$} \\
\hline 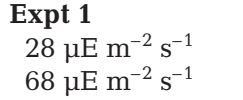 & $\begin{array}{c}0 \\
130 \\
130\end{array}$ & $\begin{array}{c}8 \\
1141 \\
3599\end{array}$ & $\begin{array}{c}13 \\
20974\end{array}$ & $\begin{array}{c}16 \\
7587 \\
36072\end{array}$ & $\begin{array}{c}20.5 \\
23822\end{array}$ & $\begin{array}{c}t_{0}-t_{8} \\
\mathbf{0 . 2 7 2} \\
\mathbf{0 . 4 1 6}\end{array}$ & $\begin{array}{l}t_{8}-t_{13} \\
0.353\end{array}$ & $\begin{array}{l}t_{13}-t_{16} \\
0.181\end{array}$ & $\begin{array}{l}t_{16}-t_{20.5} \\
0.254\end{array}$ & $\begin{array}{l}t_{8}-t_{16} \\
0.237 \\
0.288\end{array}$ \\
\hline 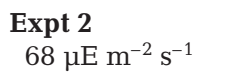 & $\begin{array}{c}0 \\
250\end{array}$ & $\begin{array}{c}16 \\
1733\end{array}$ & $\begin{array}{c}22 \\
15575\end{array}$ & & & $\begin{array}{r}t_{0}-t_{16} \\
0.121\end{array}$ & $\begin{array}{l}t_{16}-t_{22} \\
\mathbf{0 . 3 6 6}\end{array}$ & & & \\
\hline 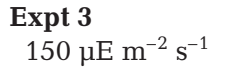 & $\begin{array}{c}0 \\
3209\end{array}$ & $\begin{array}{c}3 \\
4947\end{array}$ & $\begin{array}{c}8 \\
20161\end{array}$ & $\begin{array}{c}11 \\
28396\end{array}$ & & $\begin{array}{c}t_{0}-t_{3} \\
0.144\end{array}$ & $\begin{array}{c}t_{3}-t_{8} \\
\mathbf{0 . 2 8 1}\end{array}$ & $\begin{array}{l}t_{8}-t_{11} \\
0.114\end{array}$ & & \\
\hline $\begin{array}{l}\text { Expt } 4 \\
20 \mu \mathrm{E} \mathrm{m} \mathrm{m}^{-2} \mathrm{~s}^{-1}\end{array}$ & $\begin{array}{c}0 \\
600\end{array}$ & $\begin{array}{c}7 \\
634\end{array}$ & $\begin{array}{c}16 \\
2807\end{array}$ & $\begin{array}{c}24 \\
14204\end{array}$ & $\begin{array}{c}29 \\
27824\end{array}$ & $\begin{array}{c}t_{0}-t_{7} \\
0.008\end{array}$ & $\begin{array}{l}t_{7}-t_{16} \\
0.165\end{array}$ & $\begin{array}{l}t_{16}-t_{24} \\
\mathbf{0 . 2 0 3}\end{array}$ & $\begin{array}{l}t_{24}-t_{29} \\
0.134\end{array}$ & \\
\hline $\begin{array}{l}50 \mu \mathrm{E} \mathrm{m} \mathrm{m}^{-2} \mathrm{~s}^{-1} \\
68 \mu \mathrm{E} \mathrm{m} \mathrm{s}^{-2} \mathrm{~s}^{-1}\end{array}$ & $\begin{array}{c}0 \\
600 \\
600\end{array}$ & $\begin{array}{c}7 \\
556 \\
638\end{array}$ & $\begin{array}{c}15 \\
5764 \\
9176\end{array}$ & 28175 & $\begin{array}{c}24 \\
36247\end{array}$ & $\begin{array}{c}t_{0}-t_{7} \\
-0.01 \\
0.009\end{array}$ & $\begin{array}{l}t_{7}-t_{15} \\
\mathbf{0 . 2 9 2} \\
\mathbf{0 . 3 3 3}\end{array}$ & $\begin{array}{l}t_{15}-t_{20} \\
0.224\end{array}$ & $\begin{array}{l}t_{15}-t_{24} \\
0.204\end{array}$ & \\
\hline 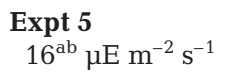 & $\begin{array}{c}0 \\
496\end{array}$ & $\begin{array}{c}27 \\
2876\end{array}$ & $\begin{array}{c}30 \\
4797\end{array}$ & $\begin{array}{c}34 \\
10600\end{array}$ & $\begin{array}{c}39 \\
22090\end{array}$ & $\begin{array}{l}t_{0}-t_{27} \\
0.065\end{array}$ & $\begin{array}{l}t_{27}-t_{30} \\
0.171\end{array}$ & $\begin{array}{c}t_{30}-t_{34} \\
\mathbf{0 . 1 9 8}\end{array}$ & $\begin{array}{l}t_{34}-t_{39} \\
0.147\end{array}$ & $\begin{array}{l}t_{27}-t_{39} \\
0.170\end{array}$ \\
\hline 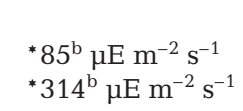 & $\begin{array}{c}27 \\
2876 \\
2876\end{array}$ & $\begin{array}{c}28 \\
3191 \\
3426\end{array}$ & $\begin{array}{c}30 \\
5372 \\
10268\end{array}$ & $\begin{array}{c}34 \\
15303 \\
13206\end{array}$ & & $\begin{array}{l}t_{27}-t_{28} \\
0.104 \\
0.175\end{array}$ & $\begin{array}{l}t_{28}-t_{30} \\
0.260 \\
0.549\end{array}$ & $\begin{array}{l}t_{30}-t_{34} \\
0.262 \\
0.063\end{array}$ & & \\
\hline 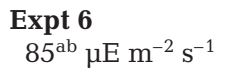 & $\begin{array}{c}0 \\
728\end{array}$ & $\begin{array}{c}8 \\
5871\end{array}$ & $\begin{array}{c}11 \\
6884\end{array}$ & $\begin{array}{c}15 \\
25388\end{array}$ & & $\begin{array}{r}t_{0}-t_{8} \\
0.261\end{array}$ & $\begin{array}{l}t_{8}-t_{11} \\
0.053\end{array}$ & $\begin{array}{l}t_{11}-t_{15} \\
\mathbf{0 . 3 2 6}\end{array}$ & $\begin{array}{l}t_{8}-t_{15} \\
0.209\end{array}$ & \\
\hline 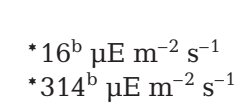 & $\begin{array}{c}8 \\
5871 \\
5871\end{array}$ & $\begin{array}{c}9 \\
4103 \\
3654\end{array}$ & 6902 & $\begin{array}{c}12 \\
7415\end{array}$ & $\begin{array}{c}15 \\
17338 \\
14750\end{array}$ & $\begin{array}{c}t_{8}-t_{9} \\
-0.358 \\
-0.474\end{array}$ & $t_{9}-t_{11}$ & $\begin{array}{l}t_{9}-t_{12} \\
0.197\end{array}$ & $\begin{array}{l}t_{11}-t_{15} \\
0.190\end{array}$ & $\begin{array}{l}t_{12}-t_{15} \\
0.283\end{array}$ \\
\hline $\begin{array}{l}\text { Expt } 7 \\
\quad 314^{\mathrm{ab}} \mu \mathrm{E} \mathrm{m} \mathrm{m}^{-2} \mathrm{~s}^{-1}\end{array}$ & $\begin{array}{c}0 \\
1555\end{array}$ & $\begin{array}{c}3 \\
1795\end{array}$ & $\begin{array}{c}7 \\
5301\end{array}$ & $\begin{array}{c}10 \\
12016\end{array}$ & $\begin{array}{c}14 \\
32092\end{array}$ & $\begin{array}{c}t_{0}-t_{3} \\
0.048\end{array}$ & $\begin{array}{r}t_{3}-t_{7} \\
0.271\end{array}$ & $\begin{array}{l}t_{7}-t_{10} \\
\mathbf{0 . 2 7 3}\end{array}$ & $\begin{array}{l}t_{10}-t_{14} \\
0.246\end{array}$ & $\begin{array}{l}t_{7}-t_{14} \\
0.257\end{array}$ \\
\hline $\begin{array}{l}{ }^{*} 85^{\mathrm{b}} \mu \mathrm{E} \mathrm{m} \mathrm{m}^{-2} \mathrm{~s}^{-1} \\
{ }^{*} 16^{\mathrm{b}} \mu \mathrm{E} \mathrm{m^{-2 }} \mathrm{s}^{-1}\end{array}$ & $\begin{array}{c}7 \\
5301 \\
5301\end{array}$ & $\begin{array}{c}8 \\
8873 \\
9175\end{array}$ & $\begin{array}{c}10 \\
14076 \\
14159\end{array}$ & $\begin{array}{c}14 \\
36449 \\
24604\end{array}$ & & $\begin{array}{c}t_{7}-t_{8} \\
0.515 \\
0.549\end{array}$ & $\begin{array}{l}t_{8}-t_{10} \\
0.231 \\
0.217\end{array}$ & $\begin{array}{l}t_{10}-t_{14} \\
0.238 \\
0.138\end{array}$ & $\begin{array}{l}t_{8}-t_{14} \\
0.235 \\
0.164\end{array}$ & \\
\hline
\end{tabular}

the growth rate of colonial Phaeocystis antarctica in iron- and nutrient-replete media at irradiance levels

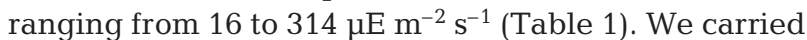
out these irradiance experiments in 1.21 polycarbonate bottles at $0^{\circ} \mathrm{C}$ under continuous fixed irradiance generated by $61 \mathrm{~cm}$ (24 in) T8 or T12 cool white flourescent lights (Philips). Marked changes in the diel light cycle are expected in the southern Ross Sea during the growing season, owing to seasonal changes in the solar angle as well as short-term changes in the depth of the surface mixed layer (Arrigo et al. 1998b, Gordon et al. 2000, Smith \& van Hilst 2004). We did not attempt to mimic these in situ temporal variations in irradiance in our experiments; instead, we chose to conduct the experiments under continuous irradiance using a range of values typical of the mean mixed-layer irradiance in the southern Ross Sea from early spring through early summer (Smith et al. 2000, Hiscock 2004, Smith \& van Hilst 2004). The growth medium used for these experiments was L1 nutrient medium (Guillard \& Hargraves 1993) diluted 457 -fold with filtered low-iron seawater (hereafter L1/457 medium), which yielded initial macronutri- ent and iron concentrations of approximately $15 \mu \mathrm{M}$ nitrate + nitrite, $1.3 \mu \mathrm{M}$ phosphate and $25 \mathrm{nM}$ dFe. Given these relatively high initial concentrations of macronutrients and iron, we assume that observed exponentialphase growth rates represent growth under iron- and nutrient-replete conditions.

The protocols used for our irradiance experiments are summarized in Fig. 2a. The experiments were initiated by diluting approximately $1 \mathrm{l}$ of colonial Phaeocystis antarctica culture in exponential growth phase to a volume in the range of 18 to 43 l, using L1/457 medium chilled to $0^{\circ} \mathrm{C}$. This produced experimental 'inoculum cultures' with initial cell densities in the range of 200 to 750 cells $\mathrm{ml}^{-1}$, with the exception of irradiance Expts $3\left(\sim 3000\right.$ cells ml $\left.{ }^{-1}\right)$ and 7 ( 1500 cells $\mathrm{ml}^{-1}$ ). These inoculum cultures were then gently mixed and used to fill multiple 1.21 polycarbonate incubation bottles, leaving $200 \mathrm{ml}$ of headspace in each bottle. In addition, subsamples were taken from the inoculum cultures for measurements of chlorophyll a ( $\mathrm{chl} \mathrm{a}$ ) concentration and cell density (in cells $\mathrm{ml}^{-1}$ ). The 1.21 bottles were immediately transferred to a refrigerated 
a

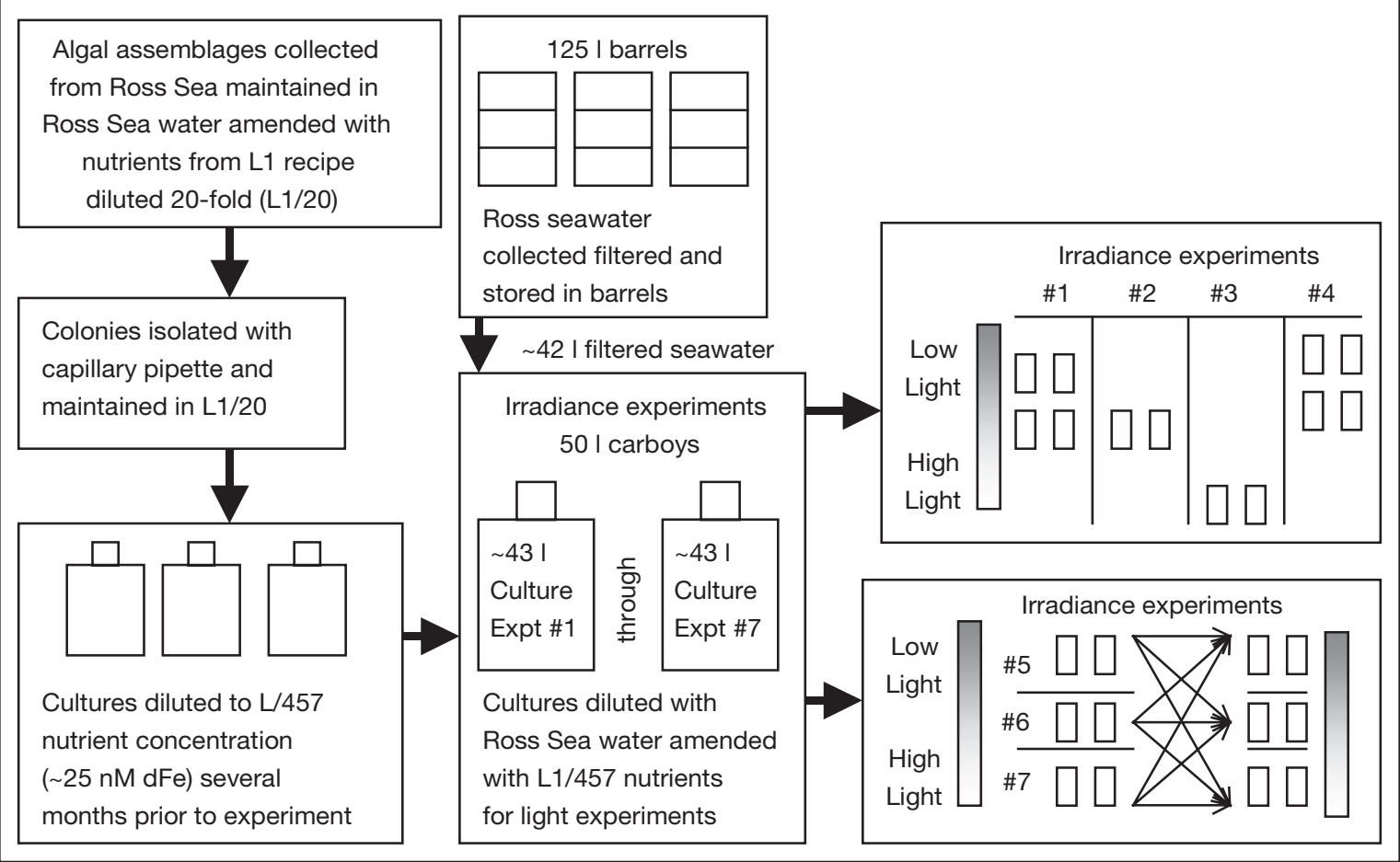

b

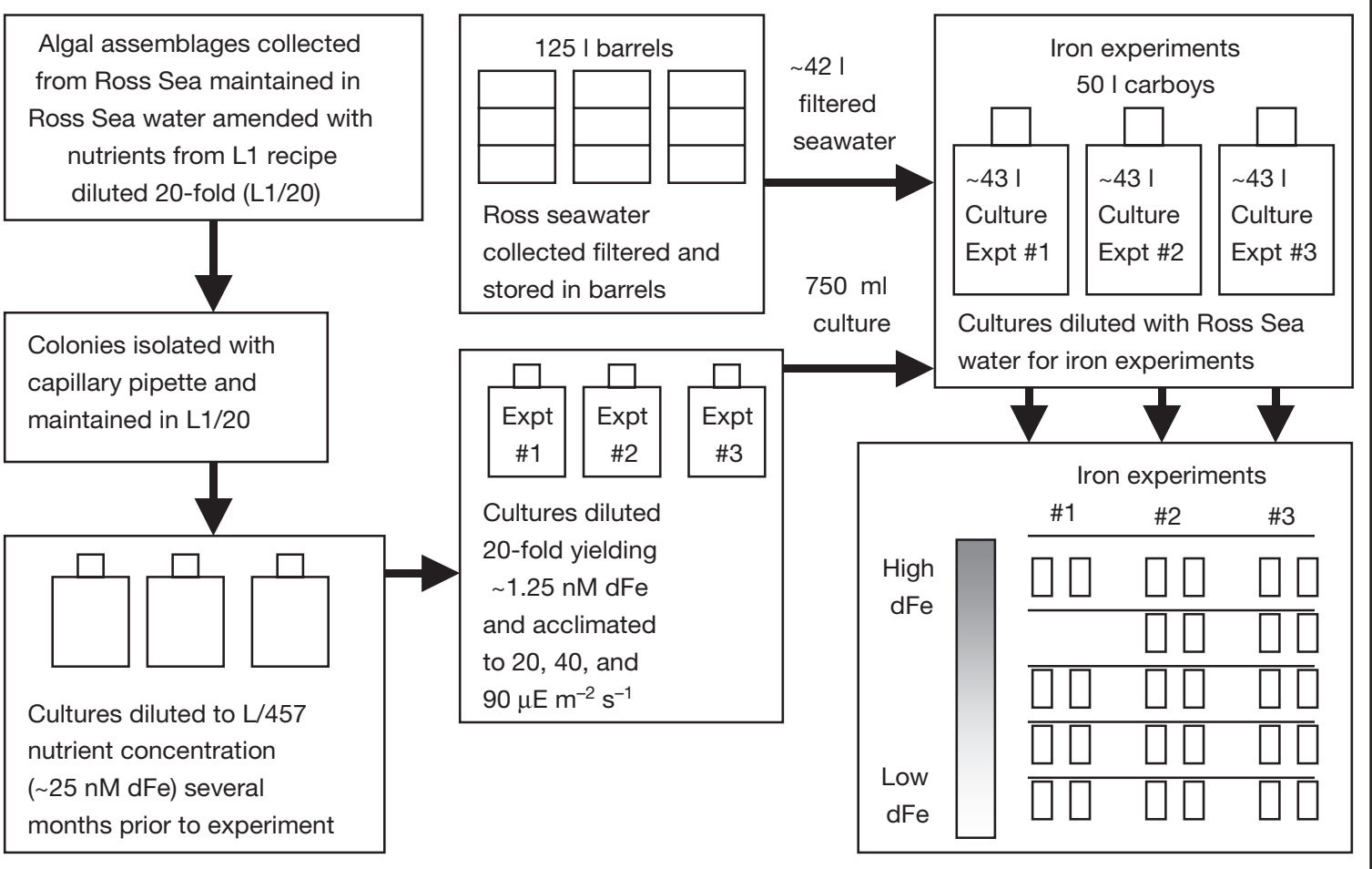

Fig. 2. Culturing techniques and protocols for (a) irradiance experiments and (b) iron-addition experiments. In Irradiance Expts 5 to 7, light intensity was changed in the middle of the experiments (see 'Materials and methods'). Irradiance was 20,40 and $90 \mu \mathrm{E} \mathrm{m}^{-2} \mathrm{~s}^{-1}$ for iron Expts 1, 2 and 3, respectively; dFe: dissolved iron 
incubator (Powers Scientific model FMS33SDF), or to an ice bath maintained in a cold room and incubated at $0^{\circ} \mathrm{C}$ over periods of 11 to $39 \mathrm{~d}$ at the fixed irradiance levels listed in Table 1. During the incubation period, duplicate 1.21 bottles were terminally subsampled (i.e. the entire incubation bottle was used in the subsampling procedure) at 3 to 4 time points for measurements of chl a concentration and total cell density. Because of the heat generated when producing high irradiance, treatments greater than $100 \mu \mathrm{E} \mathrm{m} \mathrm{m}^{-2} \mathrm{~s}^{-1}$ were incubated in an ice-water bath inside a $4^{\circ} \mathrm{C}$ cold room, rather than in the refrigerated incubator. To minimize biases due to spatial variations of the irradiance field in the incubators or ice bath, bottle positions were alternated on a daily basis. Given initial cell densities of around 500 cells $\mathrm{ml}^{-1}$ in the inoculum cultures (except irradiance Expts 3 and 7), we assume that the $P$. antarctica cells were acclimated to the experimental irradiance levels for the periods when exponential growth rates were calculated, during which total cell densities were in the range of 5000 to 10000 cells ml $^{-1}$ (see Table 1 for details). For Expts 3 and 7, cells were acclimated to experimental light levels for approximately 5 generations before the beginning of the experiments. To examine the effects of rapid changes in irradiance on cellular physiology and biochemistry of $P$. antarctica, a subset of incubation bottles from irradiance Expts 5 to 7 were exposed to a range of irradiance levels (see Table 1 [final irradiance], Fig. 2a) following acclimation to the initial experimental irradiance for periods of 7 to $27 \mathrm{~d}$.

Laboratory iron dose-response experiments. Results of preliminary laboratory and shipboard experiments indicated that colonial Phaeocystis antarctica is able to access dissolved iron that is complexed by the siderophore desferrioxamine-B (DFOB), even when DFOB is added to cultures in more than a 10-fold molar excess of total dissolved iron (Garcia 2006, Sedwick et al. 2007). These and the results of other laboratory studies (e.g. see Boyé \& van den Berg 2000, van Leeuwe \& Stefels 2007) suggest that haptophytes are able to produce specific Fe(III)-binding organic ligands and/or reduce ligand-bound Fe(III) at the cell surface (Shaked et al. 2005). With the assumption that organically complexed iron may be biologically available to $P$. antarctica, we chose to conduct our iron-addition experiments without adding synthetic organic ligands such as DFOB or EDTA to control dissolved inorganic Fe(III) concentrations. This was done to mimic chemical conditions in the marine environment. To this end, we performed experiments in which cultures of colonial $P$. antarctica were successively diluted with filtered, low-iron, Ross Sea seawater, similar to the methods described by Boyé \& van den Berg (2000) and Timmermans et al. (2001, 2004). By applying stringent trace-metal clean techniques, we were able to produce experimental unialgal inoculum cultures that were predominantly colonial cells of $P$. antarctica in a seawater medium containing low concentrations of dissolved iron ( 0.05 to $0.22 \mathrm{nM}$ ) typical of Ross Sea surface waters (Martin et al. 1990, Fitzwater et al. 2000, Sedwick et al. 2000, Coale et al. 2005).

Using this approach, we conducted iron-addition experiments to examine the effect of ambient dissolved iron concentrations on the growth of colonial Phaeocystis antarctica at irradiances of approximately 20, 40 and $90 \mu \mathrm{E} \mathrm{m} \mathrm{m}^{-2} \mathrm{~s}^{-1}$ (hereafter referred to as iron addition Expts 1, 2 and 3, respectively), as summarized in Table 2 and Fig. 2b. In these experiments, P. antarctica isolates that had been maintained as semi-continuous cultures in L1/20 medium were diluted with low-iron filtered seawater to produce primary starting cultures that were predominantly colonial $P$. antarctica in L1/457 medium ( 25 nM dFe) approximately 3 mo before the start of each experiment. These primary starting cultures were maintained in an incubator at $0^{\circ} \mathrm{C}$ at a continuous irradiance of $\sim 50 \mu \mathrm{E} \mathrm{m}^{-2} \mathrm{~s}^{-1}$. At 1 to $2 \mathrm{wk}$ before the start of each iron-addition experiment, a secondary starting culture of $P$. antarctica was prepared by diluting the primary starting culture 20-fold with $0.2 \mu \mathrm{m}$ filtered, low-iron seawater in an acidcleaned $1.2 \mathrm{l}$ polycarbonate bottle, using a trace-metal clean protocol. The resulting growth medium for these secondary starting cultures contained approximately $1.25 \mathrm{nM}$ dFe. These secondary starting cultures were acclimated to continuous irradiances of 20,40 or $90 \mu \mathrm{E}$ $\mathrm{m}^{-2} \mathrm{~s}^{-1}$ (for iron addition Expts 1, 2 or 3, respectively) at $0^{\circ} \mathrm{C}$ in a refrigerated incubator, as described for the irradiance experiments, for 1 to 2 wk before commencing the iron-addition experiments.

The iron addition experiments were initiated by removing $\sim 250 \mathrm{ml}$ of a light-acclimated secondary starting culture for initial measurements of chl $a$ and accessory pigments (see DiTullio et al. 2007). The remaining $\sim 750 \mathrm{ml}$ of the secondary starting culture was then added to 40 to $45 \mathrm{l}$ of filtered low-iron seawater that had been pre-chilled to $\sim 0^{\circ} \mathrm{C}$ in an acidcleaned 501 polyethylene carboy. Our measurements verified that the filtered low-iron seawater used to dilute the Phaeocystis antarctica cultures contained relatively low concentrations of dissolved iron: $0.17 \pm$ $0.10(\mathrm{SD}) \mathrm{nM}(\mathrm{n}=4)$ for Expt 1, $0.041 \pm 0.006(\mathrm{SD}) \mathrm{nM}$ $(\mathrm{n}=4)$ for Expt 2 and $0.071 \pm 0.013(\mathrm{SD}) \mathrm{nM}(\mathrm{n}=4)$ for Expt 3. Thus, we produced large-volume inoculum cultures of $P$. antarctica in seawater media with initial $\mathrm{dFe}$ concentrations measured in sub-samples of $0.22 \pm$ $0.00 \mathrm{nM}(\mathrm{n}=2)$ for Expt 1, $0.053 \pm 0.011 \mathrm{nM}(\mathrm{n}=2)$ for Expt 2 and $0.076 \pm 0.014 \mathrm{nM}(\mathrm{n}=2)$ for Expt 3 (Table 2), whereas the concentration of EDTA (remaining from dilution of the L1 medium) was negligible $(<0.02 \mathrm{nM})$. 
Table 2. Summary of data from iron addition experiments. Nitrate + nitrite concentration was used to calculate growth rates in Expt 1, whereas total cell density was used to calculate growth rates in Expts 2 and 3. See 'Materials and methods' for details. Data in bold text were used to calculate $K_{\mu}, \mu_{\max }$ and $r^{2}$. Error associated with $K_{\mu}$ and $\mu_{\max }$ is the SE of the slope and $y$-intercept, respectively, of the Eadie-Hofstee regression

\begin{tabular}{|c|c|c|c|c|c|c|c|c|c|c|}
\hline $\begin{array}{l}\text { Added } \\
\text { dFe (nM) }\end{array}$ & $\begin{array}{l}\text { Initial } \\
\text { total dFe } \\
\quad(\mathrm{nM})\end{array}$ & $\begin{array}{l}\text { Number } \\
\text { of } 11 \\
\text { bottles }\end{array}$ & \multicolumn{4}{|c|}{$\begin{array}{c}{\left[\mathrm{NO}_{3}^{-}+\mathrm{NO}_{2}^{-}\right](\mu \mathrm{M}) \text { or }} \\
\left.\text { total cell density (cells ml } l^{-1}\right) \text { at } \\
\text { sampling time points from } 0 \text { to } 31 \mathrm{~d}\end{array}$} & \multicolumn{3}{|c|}{$\begin{array}{l}\text { Growth period }(t, d) \\
\text { Growth rate }\left(\mathrm{d}^{-1}\right)\end{array}$} & $\begin{array}{c}K_{\mu}(\mathrm{nM} \mathrm{dFe}) \\
\mu_{\max }\left(\mathrm{d}^{-1}\right) \\
\mathrm{r}^{2}\end{array}$ \\
\hline \multicolumn{3}{|c|}{ Expt 1: $20 \mu E \mathrm{~m}^{-2} \mathrm{~s}^{-1}$} & 0 & 16 & 25 & 31 & $t_{16}-t_{25}$ & $t_{25}-t_{31}$ & $t_{16}-t_{31}$ & $0.26 \pm 0.0014$ \\
\hline 0.0 & 0.22 & 7 & 13.38 & 13.20 & 12.78 & 12.21 & 0.135 & 0.111 & 0.125 & $0.29 \pm 0.00062$ \\
\hline 0.2 & 0.42 & 7 & 13.38 & 12.96 & 11.22 & 8.16 & 0.181 & 0.147 & 0.167 & 0.99 \\
\hline 0.6 & 0.82 & 7 & 13.38 & 13.02 & 11.66 & 6.83 & 0.173 & 0.222 & 0.193 & \\
\hline $1.8^{\mathrm{a}}$ & 2.02 & 7 & 13.38 & 13.30 & 11.44 & 10.56 & 0.345 & 0.062 & 0.232 & \\
\hline \multicolumn{3}{|c|}{ Expt 2: $40 \mu E \mathrm{~m}^{-2} \mathrm{~s}^{-1}$} & 0 & 7 & 13 & 16 & $t_{7}-t_{13}$ & $t_{13}-t_{16}$ & $t_{7}-t_{16}$ & $0.045 \pm 0.0041$ \\
\hline 0.0 & 0.05 & 7 & 1102 & 1290 & 4344 & 5326 & 0.202 & 0.068 & 0.158 & $0.38 \pm 0.011$ \\
\hline 0.09 & 0.14 & 7 & 1102 & 1958 & 11490 & 12186 & 0.295 & 0.020 & 0.203 & 0.96 \\
\hline 0.18 & 0.23 & 7 & 1102 & 2000 & 12195 & 20419 & 0.301 & 0.172 & 0.258 & \\
\hline 0.36 & 0.41 & 7 & 1102 & 2073 & 15107 & 24477 & 0.331 & 0.161 & 0.274 & \\
\hline 0.72 & 0.77 & 8 & 1102 & 2181 & 19758 & 43132 & 0.367 & 0.260 & 0.332 & \\
\hline \multicolumn{3}{|c|}{ Expt 3: $90 \mu E \mathrm{~m}^{-2} \mathrm{~s}^{-1}$} & 0 & 20 & 26 & 31 & $t_{20}-t_{26}$ & $t_{26}-t_{31}$ & $t_{20}-t_{31}$ & $0.19 \pm 0.040$ \\
\hline 0.0 & 0.08 & 7 & 271 & 296 & 524 & 786 & $\mathbf{0 . 0 9 5}$ & 0.081 & 0.089 & $0.33 \pm 0.042$ \\
\hline 0.05 & 0.13 & 7 & 271 & 307 & 700 & 1255 & 0.137 & 0.117 & 0.128 & 0.84 \\
\hline 0.10 & 0.18 & 7 & 271 & 511 & 1115 & 1399 & 0.130 & 0.019 & 0.092 & \\
\hline 0.30 & 0.38 & 7 & 271 & 482 & 1871 & 5236 & 0.226 & 0.206 & 0.217 & \\
\hline 0.90 & 0.98 & 8 & 271 & 747 & 1853 & 8018 & 0.151 & 0.293 & 0.216 & \\
\hline
\end{tabular}

The resulting low-iron inoculum culture was gently mixed before removing $\sim 31$ for initial measurements of $\mathrm{dFe}$, chl $a$, macronutrients (dissolved inorganic nitrate + nitrite, phosphate, silicate), and cell density. This inoculum culture was used to fill multiple acid-washed 1.21 polycarbonate bottles that had been pre-rinsed with filtered low-iron seawater, leaving $200 \mathrm{ml}$ of headspace in each bottle. For each experiment, sufficient 1.21 bottles were filled to provide duplicate bottles for 4 to 5 different iron treatments (see Table 2, Fig. 2b). For each iron treatment, an extra 1.21 bottle was filled and incubated for the analysis of accessory pigments at the final sampling time point (see DiTullio et al. 2007). In addition, for the highest iron treatment in each experiment, an extra 1.21 bottle was filled, incubated and successively sampled during the course of the experiment to monitor changes in algal biomass and thereby select appropriate sampling time points.

During the bottle-filling process, the inoculum culture was gently mixed to minimize biases associated with settling or floating of the Phaeocystis antarctica colonies. Iron was added to each 1.21 bottle (except the control treatments) as a $17.9 \mu \mathrm{M}$ ferric nitrate solution prepared in $0.1 \%$ by volume $\mathrm{HCl}$ (Fisher trace metal grade); the nitrate and $\mathrm{HCl}$ added in this iron solution had negligible effects on the nitrate concentration and $\mathrm{pH}$ of the inoculum cultures. Once filled, the 1.21 incubation bottles were transferred into a refrigerated incubator, where they were maintained at $0^{\circ} \mathrm{C}$ under a continuous irradiance of approximately 20,40 or $90 \mu \mathrm{Em}^{-2} \mathrm{~s}^{-1}$, for iron addition Expts 1, 2 or 3, respectively. As in the irradiance experiments, bottle positions inside the incubator were alternated on a daily basis to minimize biases due to spatial variations in the irradiance field. At each sampling time point, duplicate bottles for each iron treatment were terminally sampled for analysis of chl $a$, dissolved macronutrients and cell density (cell density data from Expt 1 are considered semi-quantitative only; see 'Analytical methods' section below). To avoid contamination with iron, the preparation of the low-iron inoculum cultures and the filling of the 1.21 incubation bottles were carried out using stringent trace-metal clean techniques inside a plastic 'bubble' enclosure under positive-pressure Class-100 filtered air. In addition, all materials contacting the low-iron filtered seawater and experimental inocula were rigorously acid cleaned using methods similar to those described by Sedwick et al. (2000). Strict axenic conditions were not maintained; however, to minimize bacterial contamination of the experimental cultures the low-iron seawater used to prepare and dilute the experimental inocula was filtered through a $0.2 \mu \mathrm{m}$ Supor CritiCap capsule filter (Pall) immediately before use. In addition, the 501 inoculum carboy and 1.21 incubation bottles were thoroughly rinsed with this $0.2 \mu \mathrm{m}$ filtered seawater under Class-100 filtered air immediately before filling.

Analytical methods. Colonial and total Phaeocystis antarctica cells were enumerated using the methods 
described by Garcia (2006). Briefly, solitary Phaeocystis antarctica cell density $\left(\mathrm{n}_{\mathrm{s}}\right.$, cells ml $\left.{ }^{-1}\right)$ was estimated by loading $20 \mathrm{ml}$ of a culture sample into a Multisizer 3 particle counter (Beckman-Coulter) and counting particles in the 3 to $9 \mu \mathrm{m}$ size range. Total $P$. antarctica cell density $\left(\mathrm{n}_{\mathrm{t}}\right.$, cells ml $\left.\mathrm{m}^{-1}\right)$ was similarly estimated using a $230 \mathrm{ml}$ culture sample that was acidified to $\mathrm{pH} 3.1$ for 20 min by addition of $10 \%$ (by volume) $\mathrm{HCl}$ solution. Colonial P. antarctica cell density $\left(\mathrm{n}_{\mathrm{c}}\right.$, cells $\left.\mathrm{ml}^{-1}\right)$ was then calculated by difference as $n_{c}=n_{t}-n_{s}$. Because this cell enumeration method was developed during the course of our study, the cell density data reported for iron addition Expt 1 should be regarded as semiquantitative only. Selected sub-samples of the experimental cultures were preserved for microscopic observations and cell enumeration by adding $1 \%$ (by volume) of modified Lugol's solution (30 $\mathrm{g} \mathrm{l}^{-1}$ potassium iodide, $20 \mathrm{~g} \mathrm{l}^{-1}$ iodine, $315 \mathrm{ml} \mathrm{l}^{-1}$ ethanol, $35 \mathrm{ml} \mathrm{l}^{-1}$ gluteraldehyde, $15 \mathrm{ml} \mathrm{l}^{-1}$ glacial acetic acid), which preserves both whole colonies and solitary cells of $P$. antarctica for microscopy (V. Schoemann pers. comm.).

Dissolved inorganic nutrients (nitrate + nitrite, phosphate and silicic acid) were determined in samples filtered through $0.45 \mu \mathrm{m}$ Supor Acrodisc filters (Pall) by the Marine Science Institute Analytical Laboratory, University of California, Santa Barbara, using standard flow analysis methods. Duplicate sub-samples for measurement of particulate chl $a$ were collected by filtering cultures through GF/F glass fiber filters (Whatman) under a gentle vacuum of 1 to 2 pounds per square inch; filters were then extracted in $90 \%$ acetone for $24 \mathrm{~h}$, and chl a determined in the extracts using a 10AU fluorometer (Turner Designs) following standard Joint Global Ocean Flux Study (JGOFS) protocols (Knap et al. 1996). Dissolved iron was determined in filtered seawater and in culture samples that were filtered through $0.4 \mu \mathrm{m}$ polycarbonate membranes (Poretics) using flow injection analysis, as described by Sedwick et al. (2005). The incident irradiance for the experimental cultures was estimated by submerging a QSL100 light meter sensor (Biospherical Instruments) inside a $1.2 \mathrm{l}$ polycarbonate bottle filled with water, then recording the irradiance after $\sim 30 \mathrm{~min}$, which allowed the fluorescent lights to equilibrate with the incubator set temperature $\left(0^{\circ} \mathrm{C}\right)$.

Interpretation of experimental data. Microscope observations and particle-counter measurements indicate that all of the experimental incubations contained unialgal cultures of Phaeocystis antarctica that were dominated $(\geq 50 \%)$ by cells in colonies, and all growth rates were calculated between experimental time points when incubation cultures were numerically dominated ( $>55$ to $70 \%$ ) by colonial P. antarctica cells. Our experimentally derived data for growth rates as a function of irradiance and dissolved iron concentration are therefore assumed to be representative of the colonial form of $P$. antarctica.

We infer net growth rates $(\mu)$ in the experimental incubations from the accumulation of total Phaeocystis antarctica cells, except in the case of iron addition Expt 1, for which we use net decrease (drawdown) in dissolved nitrate + nitrite concentration as a proxy for net increase in cellular biomass, assuming balanced growth. These growth rates were calculated from increases in total cell number (or nitrate + nitrite drawdown) between sampling time points that yielded the maximum calculated growth rate for a given experimental treatment. As a result, the growth rates and associated $K_{\mu}$ and $\mu_{\max }$ values we report for iron addition Expt 1 differ from those previously reported from this experiment by Sedwick et al. (2007), who calculated growth rates using nitrate + nitrite concentrations at time points of 25 and $31 \mathrm{~d}$ for all experimental treatments. In detail, the cell-specific net growth rates for the incubation experiments were calculated from the mean total cell density $(\mathrm{N})$ of replicate bottles at successive time points $t_{1}$ and $t_{2}$, using the equation:

$$
\mu=\left[\ln \left(\mathrm{N}_{t_{2}}\right)-\ln \left(\mathrm{N}_{t_{1}}\right)\right] /\left(t_{2}-t_{1}\right)
$$

For iron addition Expt 1, in the absence of reliable cell density data, we used this same equation to calculate nitrate-specific growth rates, where $\mathrm{N}_{t_{1}}$ and $\mathrm{N}_{t_{2}}$ instead represent the net drawdown in nitrate + nitrite from the initiation of the incubations to sampling times $t_{1}$ and $t_{2}$, respectively.

Some deviations from balanced growth are likely to have occurred during our batch-type incubation experiments. For this reason, we chose not to use measured changes in chl $a$ to estimate net growth rates, because changes in irradiance and iron availability are known to cause strong variations in the cellular chl a content of Phaeocystis antarctica. Here net growth rates estimated from nitrate + nitrite drawdown, as are presented for iron addition Expt 1, are expected to be more reliable, because cellular $\mathrm{C}: \mathrm{N}$ ratios are thought to be less plastic than C:chl a ratios in the case of unbalanced growth (Stefels \& van Leeuwe 1998, van Leeuwe \& Stefels 1998, Schoemann et al. 2005). However, the potential for deviations from balanced growth mean that the nitrate-specific growth rate estimates presented for iron addition Expt 1 are less robust than the cell-specific growth rates presented for iron addition Expts 2 and 3.

Experimental uncertainties on calculated $\mu$ values were estimated by propagating the relative standard deviations on the mean total cell densities (or nitrate + nitrite drawdown), $\mathrm{N}_{t_{1}}$ and $\mathrm{N}_{t_{2}}$ through Eq. (1). To assess the statistical significance of differences in measured variables between experimental treatments, we used a 1-way ANOVA at the $95 \%$ confidence level $(\mathrm{p}<$ 
0.05); where experiments included multiple treatments, we used orthogonal comparisons to determine the statistical significance of differences between the experimental treatments.

For the iron-addition experiments, we fitted Monod (or Michaelis-Menten) saturation functions to the growth rate versus dissolved iron data, as has previously been done by Coale et al. (1996, 2003), Timmermans et al. (2001, 2004) and Blain et al. (2002). These saturation functions have the general form:

$$
\mu=\mu_{\max }\left[\mathrm{dFe} /\left(K_{\mu}+\mathrm{dFe}\right)\right]
$$

where $\mu$ is net growth rate, dFe is the initial dissolved iron concentration in the growth medium, $\mu_{\max }$ is the theoretical maximum growth rate under iron-replete conditions, and $K_{\mu}$ is the half-saturation constant for growth with respect to dissolved iron. The saturation functions were fitted to our experimental $\mu$ versus $\mathrm{dFe}$ data using a least-squares best fit to the Eadie-Hofstee linear transformation of the Monod function, in which $\mu$ is plotted against $\mu / \mathrm{dFe}$. The Monod function requires that $\mu$ versus $\mu / \mathrm{dFe}$ yields a straight line with slope $K_{\mu}$ and $y$-intercept $\mu_{\max }$. Given that there are significant uncertainties associated with our experimental estimates of $\mu$, the Eadie-Hofstee transformation should provide the most robust estimates of $K_{\mu}$ and $\mu_{\max }$ because this method assigns equal weight to all data points (Zivin \& Waud 1982). The standard error (SE) on the slope $\left(K_{\mu}\right)$ and the $y$-intercept $\left(\mu_{\max }\right)$ of the EadieHofstee regression plots was calculated with $\mathrm{R}$ statistical software.

\section{RESULTS}

\section{Growth rate as a function of irradiance}

The data from our laboratory irradiance experiments yield estimates of maximum net cell-specific growth rates for colonial Phaeocystis antarctica as a function of irradiance under iron- and nutrient-replete conditions and continuous light (Table 1, Fig. 3). These results suggest that the growth rate of colonial $P$. antarctica increases with irradiance up to an irradiance of approximately $68 \mu \mathrm{E} \mathrm{m} \mathrm{m}^{-2} \mathrm{~s}^{-1}$, where maximum cellspecific growth rates $\left(\mu_{\max }\right)$ were in the range of 0.33 to $0.42 \mathrm{~d}^{-1}$ (average $\mu_{\max }=0.37 \mathrm{~d}^{-1}$ ). For irradiances greater than $68 \mu \mathrm{E} \mathrm{m}^{-2} \mathrm{~s}^{-1}$, our data suggest a decrease in net growth rates, which decline to $0.27 \mathrm{~d}^{-1}$ at an irradiance of $314 \mu \mathrm{E} \mathrm{m}^{-2} \mathrm{~s}^{-1}$ (Fig. 3). This observed decline presumably reflected a reduction in photosynthetic rates as a result of photoinhibition, although in the case of colonial $P$. antarctica, there is also the possibility that these changes reflected unbalanced growth (see 'Discussion').

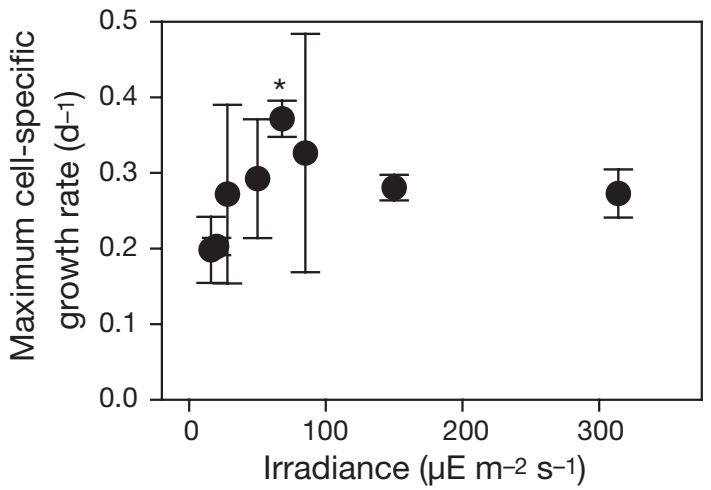

Fig. 3. Phaeocystis antarctica. Maximum cell-specific net growth rate $(\mu)$ of colonial $P$. antarctica as a function of irradiance: data are from specific irradiance experiments (see Table 1). Error bars are SE and estimated as described in 'Materials and methods', except the data point indicated by an asterisk (*) for which the error bars represent the SE on growth rates calculated from 3 separate experiments

\section{Growth rate as a function of dissolved iron}

Results of our 3 iron-addition experiments are presented in Table 2 and Fig. 4. The upper panels of Fig. 4 show mean chl a concentrations (for iron addition Expt 1, Fig. 4a) or mean total cell densities (for iron addition Expts 2 and 3, Fig. 4b,c), and the middle panels show average dissolved nitrate + nitrite concentrations $\left(\mathrm{NO}_{3}{ }^{-}+\mathrm{NO}_{2}{ }^{-}\right.$, Fig. $4 \mathrm{~d}$,f), all plotted as a function of incubation time. The lower panels show maximum net growth rates, as calculated from either $\mathrm{NO}_{3}{ }^{-}+\mathrm{NO}_{2}{ }^{-}$ drawdown (iron addition Expt 1, Fig. 4g) or increase in total cell density (iron addition Expts 2 and 3, Fig. 4h,i), all plotted as a function of initial dissolved iron concentration. These iron-addition experiments are principally diagnostic for iron deficiency: where net growth rates are significantly enhanced in experimental treatments relative to the control (or other) treatments as a result of iron amendment, we infer that growth rates in the control (or other) treatments were limited by iron deficiency.

The results of iron addition Expt 1 have been discussed by Sedwick et al. (2007). In this experiment, iron amendment resulted in significant increases in chl a (Fig. 4a) and decreases in $\mathrm{NO}_{3}{ }^{-}+\mathrm{NO}_{2}{ }^{-}$(Fig. 4d) relative to the control treatments after $31 \mathrm{~d}$ incubation. The +0.6 nM Fe treatments achieved the greatest increase in chl a $\left(\sim 5 \mu \mathrm{g} \mathrm{l}^{-1}\right)$ and drawdown of $\mathrm{NO}_{3}{ }^{-}+$ $\mathrm{NO}_{2}^{-}(\sim 6.5 \mu \mathrm{M})$, relative to the starting inoculum. Assuming that these changes reflect a net accumulation of cellular biomass in the incubation bottles, the results indicate that the growth rate of colonial Phaeocystis antarctica in the starting inoculum was limited by iron deficiency. Further, these data suggest that the 

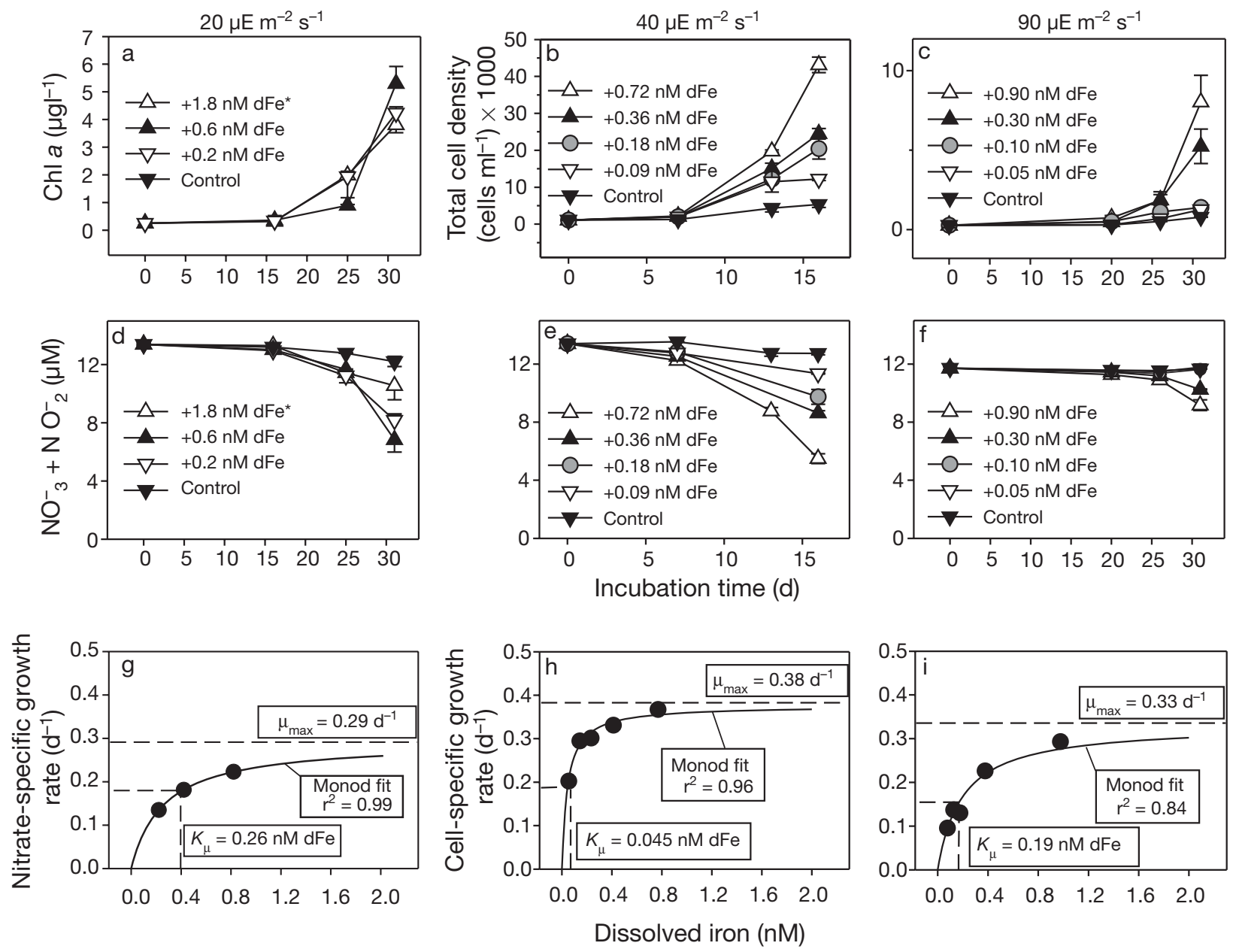

Fig. 4. Results of iron addition Expts 1, 2 and 3 (left, center and right panels, respectively). Phaeocystis antarctica (a) chlorophyll a (chl a) or (b) cell density versus incubation time for the different iron treatments. (d-f) Dissolved nitrate + nitrite versus incubation time for the different iron treatments. $(\mathrm{g})$ Nitrate- or $(\mathrm{h}, \mathrm{i})$ cell-specific maximum net growth rates of $P$. antarctica versus initial dissolved iron concentrations; also shown are Monod curves fitted using $K_{\mu}$ and $\mu_{\max }$ values estimated from Eadie-Hofstee transformation of the data (see 'Materials and methods'); $d F e$ : dissolved iron. Asterisk indicates that treatment was omitted from calculations of $K_{\mu}, \mu_{\max }$ and ${ }^{2}$ (see 'Results' and 'Discussion')

cellular biomass, hence, net growth rate of $P$. antarctica, increased in relative proportion with the dissolved iron addition, with the notable exception of the $+1.8 \mathrm{nM}$ Fe treatments, which exhibited a lesser biological response than the $+0.2 \mathrm{nM}$ and $+0.6 \mathrm{nM}$ Fe treatments (Fig. 4g). The anomalous results obtained for the $+1.8 \mathrm{nM}$ Fe treatments is thought to reflect the loss of biologically available iron from the growth medium owing to precipitation or adsorption (see 'Discussion').

There were no such anomalous results for iron addition Expts 2 and 3, in which the highest initial dissolved iron concentrations were $0.77 \mathrm{nM}$ and $0.98 \mathrm{nM}$, respectively (Table 2 ). In both of these experiments, after incubation with added iron, we observed increases in total cell density (Fig. 4b,c) that mirrored decreases in $\mathrm{NO}_{3}^{-}+\mathrm{NO}_{2}^{-}$(Fig. 4e,f) relative to the control treatments. These data indicate that the cellular biomass, total cell density and net cell-specific growth rate (Fig. 4h,i) of Phaeocystis antarctica increased according to the added concentration of dissolved iron. Clearly, a deficiency in dissolved iron limited the growth rate of $P$. antarctica in all treatments relative to the $+0.72 \mathrm{nM}$ dFe (iron addition Expt 2) and $+0.90 \mathrm{nM}$ dFe (iron addition Expt 3) treatments. The shorter duration of iron addition Expt 2 (16 versus $31 \mathrm{~d}$ for iron addition Expts 1 and 3), in which there was a more rapid biological response to the added iron, is readily explained by the higher biomass in the starting inoculum (1100 cells ml ${ }^{-1}$ for iron addtion Expt 2 compared with 175 and 270 cells ml $^{-1}$ for iron addition Expts 1 and 3 , respectively). 


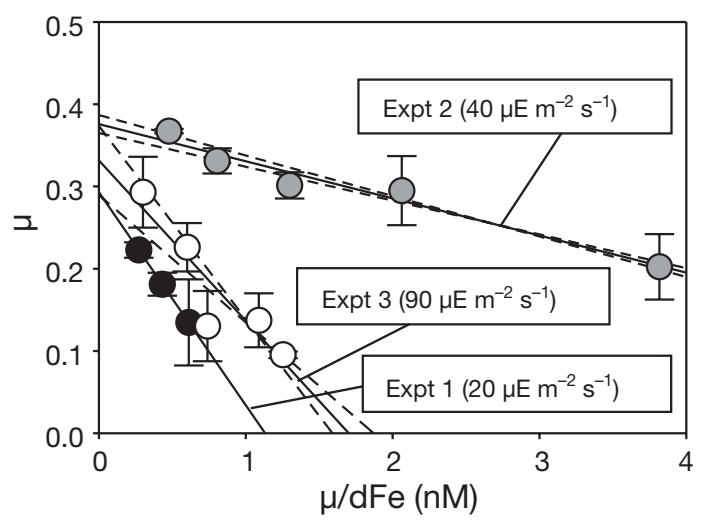

Fig. 5. Linear regression fits to the Eadie-Hofstee transformation of data from iron addition Expts 1, 2 and 3. For each line $K_{\mu}(\mathrm{nM})$ is equal to the negative slope and $\mu_{\max }\left(\mathrm{d}^{-1}\right)$ is equal to the $y$-axis intercept. Dotted lines represent \pm SE calculated for the regression equations. Error bars show the estimated experimental uncertainties on $\mu$ as described in 'Materials and methods'; dFe: dissolved iron

Using the mean maximum nitrate-specific growth rates from iron addition Expt 1, but omitting the data for the 'anomalous' +1.8 nM Fe treatment (see 'Discussion'), an Eadie-Hofstee plot yields a least squares best fit line $\left(\mathrm{r}^{2}=0.99\right)$ with a slope $\left(=-K_{\mu}\right)$ of $-0.26 \mathrm{nM}$ and $y$-intercept $\left(=\mu_{\mathrm{max}}\right)$ of $0.29 \mathrm{~d}^{-1}$ (Fig. 5). Note that these estimates differ from those reported previously by Sedwick et al. (2007), which were estimated from growth rates calculated between Days 25 and 31 of the incubation (see 'Materials and methods'). However, this revised estimate of $K_{\mu}$ for colonial Phaeocystis antarctica grown under suboptimal irradiance is still relatively high (see 'Discussion'). For iron addition Expts 2 and 3, mean maximum cellspecific net growth rates for the different iron treatments yield Eadie-Hofstee plots of $\mu$ versus $\mu / d F e$ (Fig. 5) that have best-fit linear regressions with slopes $\left(=-K_{\mu}\right)$ of $-0.045 \mathrm{nM}$ (iron addition Expt 2) and $-0.19 \mathrm{nM}$ (iron addition Expt 3), and $y$-intercepts $\left(=\mu_{\max }\right)$ of $0.38 \mathrm{~d}^{-1}$ (iron addition Expt 2 ) and $0.33 \mathrm{~d}^{-1}$ (iron addition Expt 3). These linear regressions have $\mathrm{r}^{2}$ values of 0.96 (iron addition Expt 2) and 0.84 (iron addition Expt 3). The Monod saturation functions corresponding to these $K_{\mu}$ and $\mu_{\max }$ values are plotted in Fig. 4g (iron addition Expt 1), Fig. 4h (iron addition Expt 2) and Fig. 4i (iron addition Expt 3). The estimated $K_{\mu}$ and $\mu_{\max }$ values, along with SE estimates for each, are presented in Table 2 . The $K_{\mu}$ values estimated from iron addition Expts 1 and 3 were significantly different than that from iron addition Expt 2 at the $95 \%$ confidence level, based on the interaction term of a least squares regression analysis of the Eadie-Hofstee plots.

\section{Effect of dissolved iron concentration on colony formation}

Although all of our experimental treatments were dominated by the colonial form of Phaeocystis antarctica, solitary cells were also present, and the relative proportions of these 2 forms can be estimated from our particle counter measurements (see 'Materials and methods'). Our data thus allow us to examine the influence of irradiance and iron concentrations on the relative proportions of colonial versus solitary $P$. antarctica cells. Results of the irradiance experiments reveal no systematic trend in the relative abundance of colonial and solitary cells as a function of light. However, the data from iron addition Expt 2 (irradiance, $\sim 40 \mu \mathrm{E} \mathrm{m} \mathrm{m}^{-2} \mathrm{~s}^{-1}$ ) suggest that iron amendment had a significant effect on the relative proportion of colonial cells (ANOVA parameters, $F_{4,14}=9.00, \mathrm{p}=$ 0.002). In this experiment, the high iron treatments $(+0.72 \mathrm{nM} \mathrm{Fe})$ contained an average of $96 \%$ colonial cells compared with an average of $74 \%$ colonial cells in the control treatments after $16 \mathrm{~d}$ incubation (Fig. 6a). In contrast, iron amendment did not have a significant effect on the proportion of solitary versus colonial cells in iron addition Expt 3 (irradiance, $\sim 90 \mu \mathrm{E} \mathrm{m} \mathrm{m}^{-2} \mathrm{~s}^{-1}$, Fig. 6b). This may in part reflect differences in the starting inoculum for iron addition Expts 2 and 3, given the relatively high proportion of single cells (nearly $50 \%$ of total cells) and low dFe concentration $(0.05 \mathrm{nM})$ in the starting inoculum used for iron addition Expt 2-data acquired from the starting inoculum are semi-quantitative because solitary cells were counted after colonies were preserved with a Lugol's-gluteraldehyde solution (Garcia 2006). Unfortunately, we are lacking quantitative information on the relative proportion of solitary and colonial cells in the starting inoculum for iron addition Expt 3 and for all treatments in iron addition Expt 1, which was carried out before the cell-counting method had been optimized.

\section{Changes in cellular chl $a$ as a function of irradiance and iron}

The cellular chl a content of Phaeocystis antarctica is known to vary significantly in response to changes in irradiance and iron availability. This point is clearly demonstrated by the results of our irradiance and ironaddition experiments, for which our cell-counting method allows estimates of chl a per cell. For irradiance Expts 5, 6 and 7, in which selected incubation bottles were exposed to higher or lower irradiance after a period of acclimation to the nominal experimental irradiance, we observed significant corresponding 


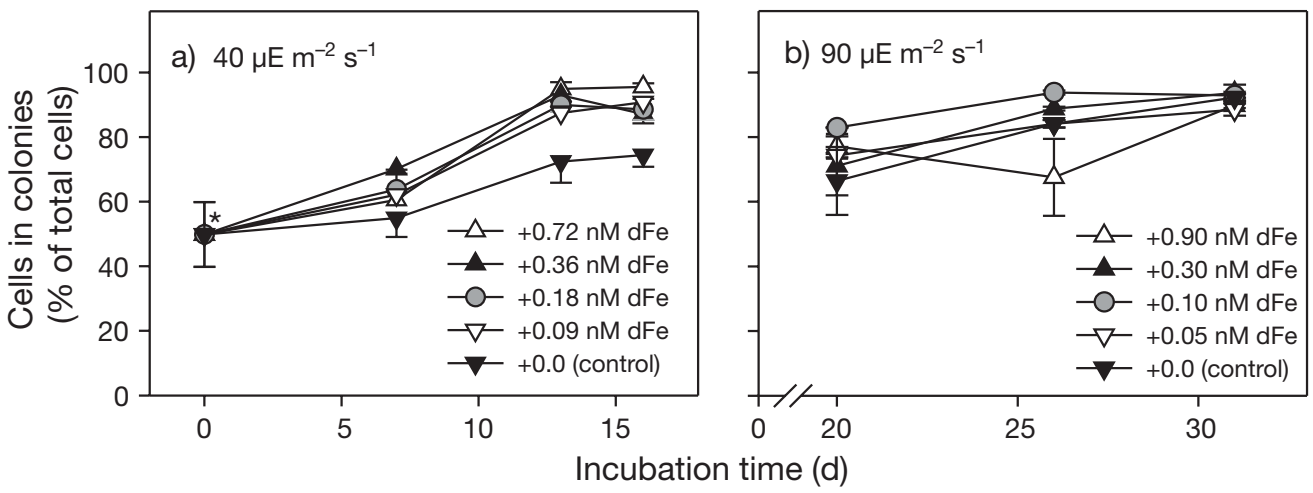

Fig. 6. Phaeocystis antarctica. Proportion of cells in colonial form as a function of incubation time in (a) iron addition Expt 2 and (b) iron addition Expt 3. Cell density data at the initial time point of iron addition Expt 2 (indicated by asterisk) are semi-quantitative only; dFe: dissolved iron
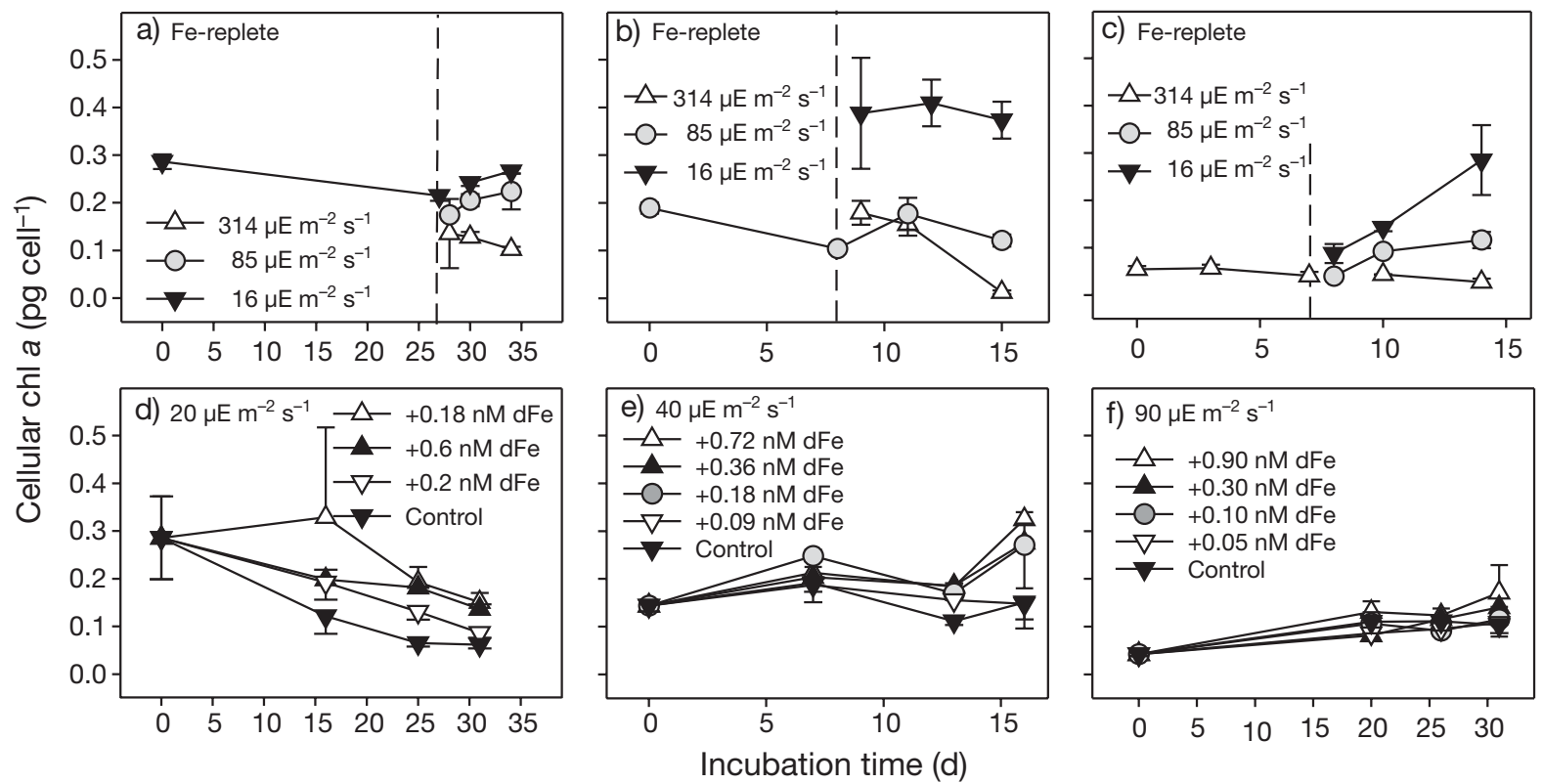

Fig. 7. Phaeocystis antarctica. Effect of changes in irradiance (top panels) and dissolved iron concentration (bottom panels) on cellular chlorophyll a (chl a). Cultures were acclimated to 16,85 and $314 \mu \mathrm{E} \mathrm{m}^{-2} \mathrm{~s}^{-1}$ in (a) irradiance Expt 5, (b) irradiance Expt 6 and (c) irradiance Expt 7, respectively (dashed line indicates time when subset of light-acclimated cultures were exposed to different irradiance levels). Bottom panels show results from (d) iron addition Expt 1 (data are semi-quantitative only), (e) iron addition Expt 2 and (f) iron addition Expt 3; dFe: dissolved iron

decreases or increases in cellular chl $a$, respectively (Fig. $7 \mathrm{a}-\mathrm{C}$ ). In addition, the results of iron addition Expt 2 (Fig. 7e) indicate that amendment of cultures with dissolved iron mediated significant increases in cellular chl $a$, relative to the control treatments. Data from iron addition Expts 1 and 3 also followed this trend, although the differences between treatments were not statistically significant for iron addition Expt 3 (Fig. 7f), whereas the cellular chl a data from iron addition Expt 1 (Fig. 7 d) are semi-quantitative only (see 'Materials and methods').

\section{DISCUSSION}

\section{Irradiance and growth of colonial Phaeocystis antarctica}

Despite significant uncertainties in the growth rates estimated from our irradiance experiments (Table 1, Fig. 3), the data suggest that colonial Phaeocystis antarctica achieves a maximum growth rate under ironand nutrient-replete conditions at a constant irradiance of around $70 \mu \mathrm{E} \mathrm{m}^{-2} \mathrm{~s}^{-1}$, with a clear decrease in growth 
rate observed at higher irradiance values. These results are consistent with the photosynthesis versus irradiance data reported by van Hilst \& Smith (2002), which suggest that $P$. antarctica exhibits maximum rates of photosynthesis for irradiance values in the range of $\sim 50$ to $130 \mu \mathrm{E} \mathrm{m}^{-2} \mathrm{~s}^{-1}$ and lower rates at higher irradiance. Our findings are also supported by the results of culture experiments reported by Dehairs et al. (2006), which show photoinhibition of $P$. antarctica at irradiances greater than $\sim 100 \mu \mathrm{E} \mathrm{m}^{-2} \mathrm{~s}^{-1}$ on an $18 \mathrm{~h}: 6 \mathrm{~h}$ dark:light cycle under nutrient-replete conditions. Hence, the decline in cell-specific growth rates observed in our culture experiments probably reflects a reduction in photosynthetic rate, i.e. the onset of photoinhibition. To some extent, the lower growth rates apparent at a higher irradiance might also reflect a departure from balanced growth, given that colonial $P$. antarctica is known to produce substantial quantities of intra- and extra-cellular carbohydrates as well as other organic compounds. These photosynthetic products may serve as stored reserves of respirable carbon (Mathot et al. 2000) or reduce the photodamage to cells exposed to supraoptimal irradiance (van Leeuwe \& Stefels 2007).

In comparison with our experimental light levels, estimates of mean mixed-layer irradiance in the southern Ross Sea are $\sim 80$ to $100 \mu \mathrm{E} \mathrm{m}^{-2} \mathrm{~s}^{-1}$ in late spring to early summer, and $\sim 180 \mu \mathrm{E} \mathrm{m} \mathrm{m}^{-2} \mathrm{~s}^{-1}$ in midsummer (Smith \& van Hilst 2004). Thus, our experimental data are consistent with the conceptual model of Arrigo et al. (2003), whereby the mean irradiance increases as the growing season progresses and the growth rate of colonial Phaeocystis antarctica is reduced by photoinhibition. An important caveat in comparing our experimental data with in situ conditions is the use of continuous light in our experiments versus time-varying irradiance in the field, given that photoinhibition is dependent on both the intensity and duration of incident light (Falkowski \& Raven 2007). Because our cultures were incubated under continuous irradiance, we might expect to observe the effects of photoinhibition at a lower irradiance in our laboratory experiments relative to the mean irradiance at which colonial $P$. antarctica would experience photoinhibition in the field. Nevertheless, our experimental data suggest that colonial $P$. antarctica is most probably subject to photoinhibition in the southern Ross Sea as the growing season progresses and that supraoptimal irradiance may play a role in terminating the annual $P$. antarctica blooms in this region.

\section{Iron requirements for growth of colonial Phaeocystis antarctica}

In discussing our experimental results, it is important to recognize that both the chemical speciation of dissolved iron and the intrinsic iron-dependent growth rate of phytoplankton are likely to vary as a function of irradiance. This prevents us from deriving the true physiological dependence of Phaeocystis antarctica growth rate on 'biologically available iron' as a function of irradiance. However, that is not the aim of this study; rather, we set out to determine the dependence of the growth rate of colonial P. antarctica on the concentration of 'dissolved iron' as a function of irradiance, where dissolved iron is operationally defined by filtration. We reason that this information is most useful at the present time, when the majority of field data report dissolved iron rather than biologically available iron, which is not yet clearly defined and may vary depending on the phytoplankton species in question. Furthermore, most regional to larger scale biogeochemical and ecological models equate dissolved iron with biologically available iron (e.g. see Moore et al. 2004). Thus, in this study we have estimated what might be termed the 'effective' iron requirements for growth of colonial $P$. antarctica as a function of irradiance, in that our experimental estimates of $K_{\mu}$ implicitly include the effects of irradiance on the chemical speciation of dissolved iron.

During the course of our iron-addition experiments, there will have been some decrease in the dissolved iron concentration of the growth media from the initial values due to algal iron uptake and possible adsorption of iron to the container walls. However, as in other studies that have used bioassay experiments to examine the relationship between algal growth rates and dissolved iron concentrations (e.g. Coale et al. 1996, 2003, Timmermans et al. 2001, 2004, Blain et al. 2002), we interpret the results of our experiments with the assumption that the maximum observed growth rates primarily reflect the initial dissolved iron concentration of each incubation bottle, i.e. dissolved iron in the inoculum culture plus the iron added to that bottle (with the exception of the 'anomalous' $+1.8 \mathrm{nM} \mathrm{Fe}$ treatments in iron addition Expt 1; see later discussion). Some support for this assumption comes from the results of Antarctic iron-addition experiments, both in situ and in vitro, in which biological response typically lags behind the addition of iron by as much as a week (e.g. Martin et al. 1990, Boyd et al. 2000, Coale et al. 2003). Such results imply a significant hysteresis between algal growth rates and changes in dissolved iron availability. With this assumption, our data may be used to infer relationships between the net growth rate of colonial Phaeocystis antarctica and the dissolved iron concentration of the growth medium.

We speculate that the apparently anomalous results for the $+1.8 \mathrm{nM}$ Fe treatments in iron addition Expt 1 may reflect an effective 'solubility limit' for the concen- 
tration of dissolved iron in long-term bottle incubations, whereby initial dFe concentrations greater than $\sim 2 \mathrm{nM}$ result in a significant loss of biologically available iron from the growth medium via precipitation, particle scavenging and/or container-wall adsorption (Bergquist et al. 2007, Fischer et al. 2007). In the absence of added chelating agents, such as EDTA, this putative 'solubility limit' is likely to be dependent on the concentration of natural iron-binding organic ligands that are present in the seawater growth medium (Kuma et al. 1996, Johnson et al. 1997, Nakabayashi et al. 2002).

The results of our iron-addition experiments are not entirely consistent with the assumption that colonial Phaeocystis antarctica have low iron requirements for growth relative to diatoms (Arrigo et al. 2003, Tagliabue \& Arrigo 2005). For colonial $P$. antarctica, our experimental data yield estimates of the half-saturation constant for growth with respect to dissolved iron of 0.045 to $0.26 \mathrm{nM}$, for irradiance levels typical of the mean mixed-layer irradiance in the southern Ross Sea during spring through early summer. These estimates compare with $K_{\mu}$ values of 0.19 to $1.1 \mathrm{nM}$ estimated for 4 species of Antarctic

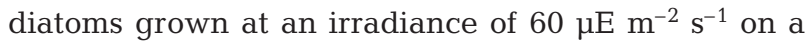
16 h:8 h light:dark cycle (Timmermans et al. 2004). Hence, our data indicate that colonial $P$. antarctica has iron requirements for growth that are similar to those of larger oceanic phytoplankton, a result which suggests that uptake of dissolved iron by colonial $P$. antarctica may be limited by diffusion of iron into the colonies, rather than diffusion into individual cells (see Morel et al. 1991, Schoemann et al. 2005). Some support for this idea is provided by the results of iron addition Expt 2, for which the starting inoculum had the lowest dissolved iron concentration (0.05 nM). In this experiment, we observed a significant increase in the proportion of colonial cells in response to iron addition. Furthermore, recent experimental results reported by Becquevort et al. (2007) and van Leeuwe \& Stefels (2007) have suggested a predominance of solitary $P$. antarctica cells under conditions of iron limitation versus domination by colonial cells in ironreplete cultures.

Together, these observations imply that solitary Phaeocystis antarctica cells are better adapted to growth at low dissolved iron concentrations. This suggestion has previously been advanced by Smith et al. (2003b), who reported an increased proportion of solitary cells in the Ross Sea during late summer when dissolved iron concentrations are lowest (Fitzwater et al. 2000, Sedwick et al. 2000, Coale et al. 2005), and is consistent with observations of elevated nutrient requirements in colonial Phaeocystis relative to solitary cells (Schoemann et al. 2005). Accepting a higher iron requirement for growth of colonial versus solitary $P$. antarctica allows us to reconcile our $K_{\mu}$ estimates with the much lower $K_{\mu}$ values (0.005 to $0.043 \mathrm{nM}$ ) estimated for haptophytes in the Ross Sea during late summer (Coale et al. 2003), assuming that these haptophytes were dominated by solitary $P$. antarctica cells. Smith et al. (2003b) also note that solitary P. antarctica cells dominate the southern Ross Sea in the early spring, pre-bloom period. This predominance of solitary $P$. antarctica cells may reflect higher growth rates compared with colonial cells owing to the lower iron requirements of solitary cells, which may be important during early spring when mean irradiance is low (see later discussion).

Our experimental data indicate that the $K_{\mu}$ value for colonial Phaeocystis antarctica varies strongly as a function of irradiance (Table 2). The roughly 5-fold decrease in $K_{\mu}$ as irradiance was increased from $\sim 20$ to

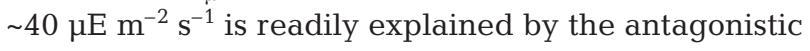
relationship between cellular iron requirements and irradiance, whereby phytoplankton require more iron per cell to maintain growth under low irradiance (Raven 1990, Sunda \& Huntsman 1997, Sedwick et al. 2007, van Leeuwe \& Stefels 2007). Assuming that colonial $P$. antarctica has only a limited ability to increase the efficiency of cellular iron uptake and/or access stored iron reserves, we would then expect that higher ambient concentrations of dissolved iron are needed to maintain growth under low irradiance, when cellular iron requirements are elevated; i.e., we would expect a higher $K_{\mu}$ value for colonial $P$. antarctica growing under suboptimal irradiance. However, the apparent 4 -fold increase in $K_{\mu}$ between experimental irradiances of $\sim 40$ and $\sim 90 \mu \mathrm{E} \mathrm{m}^{-2} \mathrm{~s}^{-1}$ (Table 2) is not as easily understood. The growth rate versus irradiance data shown in Fig. 3 suggest that continuous irradiances greater than $\sim 70 \mu \mathrm{E} \mathrm{m} \mathrm{m}^{-2} \mathrm{~s}^{-1}$ are supraoptimal for the growth of colonial $P$. antarctica. To limit photodamage under sustained conditions of supraoptimal irradiance, $P$. antarctica is thought to synthesize photoprotective pigment-protein complexes and employ various biochemical quenching mechanisms (van Leeuwe \& Stefels 2007). Importantly, some of these processes involve protein complexes in which iron plays an essential role and, therefore, may be less effective under conditions of iron limitation (van Leeuwe \& Stefels 2007). On this basis, we suggest that the iron requirements for growth of colonial $P$. antarctica, as indicated by $K_{\mu}$, might be expected to increase as irradiance increases above optimum levels, in order to limit photodamage. Thus, we infer that the iron requirements for growth of colonial $P$. antarctica reach a minimum under optimum irradiance, but increase significantly under both suboptimal and supraoptimal irradiance conditions. 


\section{Irradiance, iron availability and seasonal bloom dynamics}

In the following discussion we consider the potential for 'iron limitation' of colonial Phaeocystis antarctica based on the definition of Morel et al. (1991), who uses an iron concentration of less than $K_{\mu}$ as the criterion for 'appreciably decreased growth rate.' Therefore, we consider colonial $P$. antarctica growth to be limited by iron deficiency when the ambient concentration of dissolved iron is less than $K_{\mu}$. Further, we assume that biologically available iron corresponds to operationally defined dissolved iron, as discussed previously.

The apparent light-dependent variations in the iron requirements for growth of colonial Phaeocystis antarctica have important implications for the seasonal dynamics of this species in the southern Ross Sea. Between early spring and midsummer, mean mixedlayer irradiance in these waters increases from very low values to around $200 \mu \mathrm{E} \mathrm{m}^{-2} \mathrm{~s}^{-1}$ (Smith \& van Hilst 2004). Over the same period dissolved iron concentrations are thought to decrease from $\sim 0.2-0.5 \mathrm{nM}$ or more to $<0.2 \mathrm{nM}$, as a result of uptake by phytoplankton, particle scavenging and vertical export of organic matter (Fitzwater et al. 2000, Sedwick et al. 2000, Coale et al. 2005). In the context of these seasonal changes, our experimental results suggest a simple conceptual model that builds on ideas previously discussed by Boyd (2002) and Sedwick et al. (2007) by considering the effects of photoinhibition on the iron requirements for growth of colonial $P$. antarctica.

In this model the iron requirements for growth of colonial Phaeocystis antarctica decrease from early spring through late spring to early summer as the mean mixed-layer irradiance increases from suboptimal to near optimal levels. During this period the iron requirements for growth of colonial $P$. antarctica (i.e. the values of $K_{\mu}$ ) fall below the ambient dissolved iron concentrations in the surface mixed layer, leading to high net growth rates, the development of colonial $P$. antarctica blooms and a concomitant drawdown of dissolved iron. As the growing season further progresses into summer, mean irradiance increases to supraoptimal levels such that photoinhibition results in increased iron requirements for growth of colonial $P$. antarctica. (i.e. increases in $K_{\mu}$ ). Dissolved iron concentrations are eventually depleted to values less than $K_{\mu}$ at which point colonial $P$. antarctica experiences iron limitation to the extent that growth rates are appreciably reduced, ultimately leading to the termination of the colonial $P$. antarctica bloom. The hypothetical seasonal progression of mean irradiance, dissolved iron availability and $K_{\mu}$ are illustrated schematically in Fig. 8. Of course, these seasonal dynamics will be influenced by spatial and temporal variations in verti-

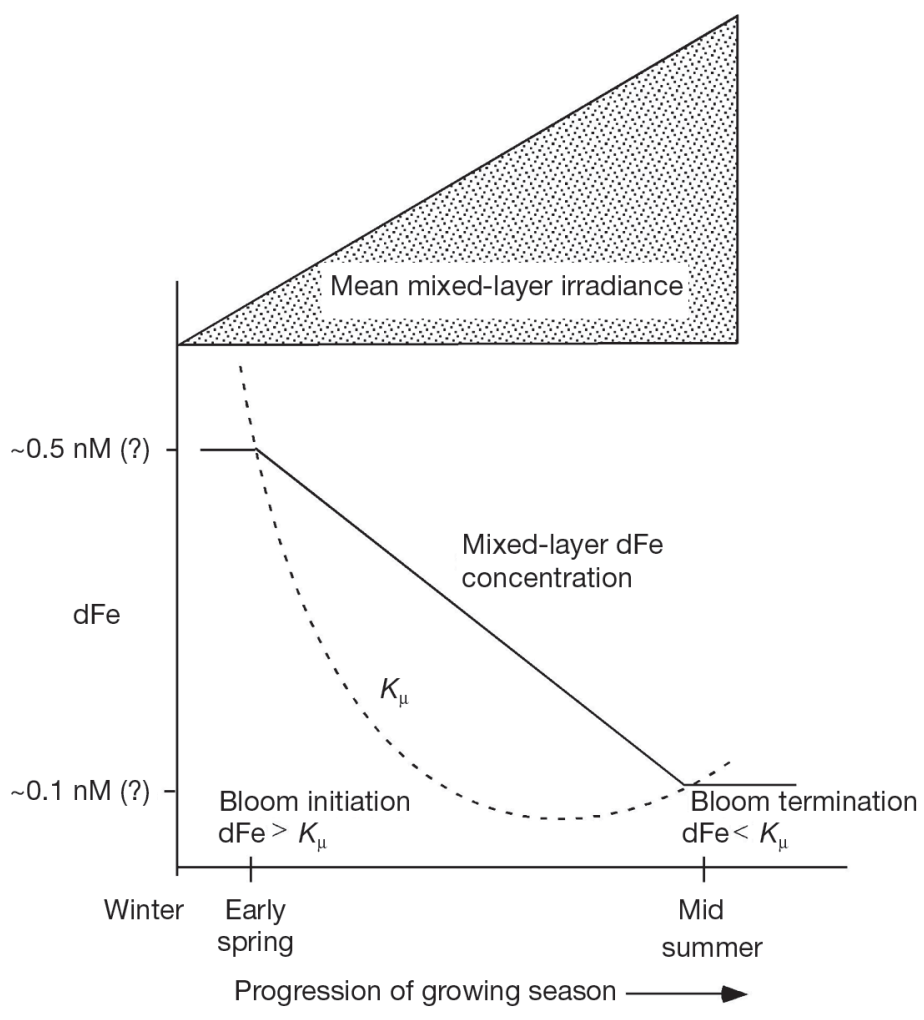

Fig. 8. Phaeocystis antarctica. Schematic representation of conceptual model for seasonal dynamics of colonial blooms in the southern Ross Sea. Bloom is maintained over the period when ambient dissolved iron concentrations (solid line) are greater than $K_{\mu}$ (dashed curve); stippled wedge at top represents seasonal increase in mean irradiance (see 'Discussion'); dFe: dissolved iron

cal mixing and dissolved iron concentrations, among other factors, which can be significant in the southern Ross Sea (e.g. see Sedwick \& DiTullio 1997, Sedwick et al. 2000, Smith \& van Hilst 2004).

\section{CONCLUSIONS}

Using controlled laboratory culture experiments we have identified significant irradiance-dependent changes in the iron requirements for growth of colonial Phaeocystis antarctica. Our results indicate that the iron requirements for growth of colonial $P$. antarctica, which are quantitatively represented by $K_{\mu}$, are significantly elevated under conditions of both suboptimal and supraoptimal mean irradiance. Although our experimental conditions are greatly simplified compared with the natural system, particularly the irradiance field, our results provide a conceptual basis for a qualitative model of the seasonal dynamics of colonial $P$. antarctica in the southern Ross Sea. To progress from this conceptual framework toward quantitative 
numerical simulations and predictions will require further experimental studies incorporating realistic timevarying irradiance (e.g. see van Leeuwe \& Stefels 2007), as well as realistic ranges of dissolved iron concentrations, like those employed in this study. In addition, several important factors still remain to be studied, including the effects of UV radiation on photosynthesis and cell physiology and the Fe/C uptake ratio (cellular iron quota) of $P$. antarctica, which is an important parameter in biogeochemical models.

Acknowledgements. We thank S. F. Riseman and C. M. Marsay for their careful assistance with experimental and analytical work. We are grateful to the officers and crew of RV 'Nathaniel B. Palmer' and personnel of the Raytheon Polar Services Company for assistance with the field collections. Principal funding for this research was provided by U.S. National Science Foundation grants OPP-0230513 (G.R.D.), OPP-0230559 (P.N.S.), and DGE-0139313 (N.S.G. through M. Vansickle and G. Tempel).

\section{LITERATURE CITED}

Arrigo KR, Tagliabue A (2005) Iron in the Ross Sea: 2. Impact of discrete iron addition strategies. J Geophys Res 110, C03010, doi:10.1029/2004JC002568

Arrigo KR, van Dijken GL (2003) Phytoplankton dynamics within 37 Antarctic coastal polynya systems. J Geophys Res 108(C8), 3271, doi: 10.1029/2002JC001739

Arrigo KR, van Dijken GL (2004) Annual changes in sea ice, chlorophyll $a$, and primary production in the Ross Sea, Antarctica. Deep-Sea Res II 51:117-138

Arrigo KR, Worthen D, Schnell A, Lizotte MP (1998a) Primary production in Southern Ocean waters. J Geophys Res 103: $15587-15600$

Arrigo KR, Weiss AM, Smith WO (1998b) Physical forcing of phytoplankton dynamics in the southwestern Ross Sea. J Geophys Res 103:1007-1021

Arrigo KR, Robinson DH, Worthen DL, Dunbar RB, DiTullio GR, VanWoert ML, Lizotte MP (1999) Phytoplankton community structure and the drawdown of nutrients and $\mathrm{CO}_{2}$ in the Southern Ocean. Science 283:365-367

Arrigo KR, Worthen DL, Robinson DH (2003) A coupled ocean-ecosystem model of the Ross Sea: 2. Iron regulation of phytoplankton taxonomic variability and primary production. J Geophys Res 108(C7), 3231, doi 10.1029/ 2001JC000856

Becquevort S, Lancelot C, Schoemann V (2007) The role of iron in the bacterial degradation of organic matter derived from Phaeocystis antarctica. Biogeochemistry 83:119-135

> Bergquist BA, Wu J, Boyle EA (2007) Variability in oceanic dissolved iron is dominated by the colloidal fraction. Geochim Cosmochim Acta 71:2960-2974

Bertrand EM, Saito MA, Rose JM, Riesselman CR and others (2007) Vitamin $B_{12}$ and iron colimitation of phytoplankton growth in the Ross Sea. Limnol Oceanogr 52:1079-1093

Blain S, Sedwick PN, Griffiths FB, Quéguiner B and others (2002) Quantification of algal iron requirements in the Subantarctic Southern Ocean (Indian sector). Deep-Sea Res II 49:3255-3273

Boyd PW (2002) Environmental factors controlling phytoplankton processes in the Southern Ocean. J Phycol 38: 844-861
Boyd PW, Watson AJ, Law CS, Abraham ER and others (2000) A mesoscale phytoplankton bloom in the polar Southern Ocean stimulated by iron fertilization. Nature 407: 695-702

Boyé M, van den Berg CMG (2000) Iron availability and the release of iron-complexing ligands by Emiliania huxleyi. Mar Chem 70:277-287

Bunt JS, Wood EJF (1963) Microbiology of antarctic sea-ice: microalgae and antarctic sea-ice. Nature 199:1254-1255

Caron DA, Dennett MR, Lonsdale DJ, Moran DM, Shalapyonok L (2000) Microzooplankton herbivory in the Ross Sea, Antarctica. Deep-Sea Res II 47:3249-3272

> Coale KH, Fitzwater SE, Gordon RM, Johnson KS, Barber RT (1996) Control of community growth and export production by upwelled iron in the equatorial Pacific Ocean. Nature 379:621-624

Coale KH, Wang X, Tanner SJ, Johnson KS (2003) Phytoplankton growth and biological response to iron and zinc addition in the Ross Sea and Antarctic Circumpolar Current along $170^{\circ} \mathrm{W}$. Deep-Sea Res II 50:635-653

Coale KH, Gordon LI, Wang X (2005) The distribution and behavior of dissolved and particulate iron and zinc in the Ross Sea and Antarctic circumpolar current along $170^{\circ} \mathrm{W}$. Deep-Sea Res I 52:295-318

> Comiso JC, McClain CR, Sullivan CW, Ryan JP, Leonard CL (1993) Coastal zone color scanner pigment concentrations in the Southern Ocean and relationships to geophysical surface features. J Geophys Res 98:2419-2451

Dehairs F, Lancelot C, André L, Gosse H and others (2006) Assesing the sensitivity of the Southern Ocean's biological carbon pump to climate change (BELCANTO II). Final report. Belgian Science Policy, Brussels

DiTullio GR, Smith WO (1995) Relationship between dimethylsulfide and phytoplankton pigment concentrations in the Ross Sea, Antarctica. Deep-Sea Res I 42: 873-892

DiTullio GR, Smith WO (1996) Spatial patterns in phytoplankton biomass and pigment distributions in the Ross Sea. J Geophys Res 101:18467-18477

DiTullio GR, Grebmeier JM, Arrigo KR, Lizotte MP and others (2000) Rapid and early export of Phaeocystis antarctica blooms in the Ross Sea, Antarctica. Nature 404:595-598

DiTullio GR, Garcia N, Riseman SF, Sedwick PN (2007) Effects of iron concentration on pigment composition in Phaeocystis antarctica grown at low irradiance. Biogeochemistry 83:71-81

El-Sayed S, Biggs DC, Holm-Hansen OH (1983) Phytoplankton standing crop, primary productivity, and near-surface nitrogenous nutrient fields in the Ross Sea, Antarctica. Deep-Sea Res 30:871-886

Falkowski PG, Raven JA (eds) (2007) Aquatic photosynthesis. Princeton University Press, Princeton, NJ

Fischer AC, Kroon JJ, Verburg TG, Teunissen T, Wolterbeek HT (2007) On the relevance of iron adsorption to container materials in small-volume experiments on iron marine chemistry: ${ }^{55} \mathrm{Fe}$-aided assessment of capacity, affinity and kinetics. Mar Chem 107:533-546

Fitzwater SE, Johnson KS, Gordon RM, Coale KH, Smith WO (2000) Trace metal concentrations in the Ross Sea and their relationship with nutrients and growth. Deep-Sea Res II 47:3159-3179

Garcia NS (2006) Effects of light and iron on the growth of colonial Phaeocystis antarctica. MS thesis, College of Charleston, Charleston, SC

Gibson JAE, Garrick RC, Burton HR, McTaggart AR (1990) Dimethylsulfide and the alga Phaeocystis pouchetii in Antarctic coastal waters. Mar Biol 104:339-346 
Goffart A, Catalano G, Hecq JH (2000) Factors controlling the distribution of diatoms and Phaeocystis in the Ross Sea. J Mar Syst 27:161-175

> Gordon LI, Codispoti LA, Jennings A, Millero FJ, Morrison JM, Sweeney C (2000) Seasonal evolution of hydrographic properties in the Ross Sea, Antarctica, 1996-1997. DeepSea Res II 47:3095-3117

Guillard R, Hargraves P (1993) Stichochrysis immobilis is a diatom, not a chrysophyte. Phycologia 32:234-236

Hiscock MR (2004) The regulation of primary productivity in the Southern Ocean. PhD thesis, Duke University, Durham, NC

> Johnson KS, Gordon RM, Coale KH (1997) What controls dissolved iron concentrations in the world ocean? Mar Chem 57:137-161

Knap A, Michaels A, Close A, Ducklow H, Dickson A (1996) Protocols for the Joint Global Ocean Flux Study (JGOFS) core measurements. JGOFS Report 19

Kuma K, Nishioka J, Matsunaga K (1996) Controls on iron(III) hydroxide solubility in seawater: the influence of $\mathrm{pH}$ and natural organic chelators. Limnol Oceanogr 41:396-407

> Leventer AR, Dunbar RB (1996) Factors influencing the distribution of diatoms and other algae in the Ross Sea. J Geophys Res 101:18489-18500

> Martin JH, Fitzwater SE, Gordon RM (1990) Iron deficiency limits plankton growth in Antarctic waters. Global Biogeochem Cycles 4:5-12

Mathot S, Smith WO, Carlson CA, Garrison DL, Gowing MM, Vickers CL (2000) Carbon partitioning in Phaeocystis antarctica (Prymnesiophyceae) colonies in the Ross Sea, Antarctica. J Phycol 36:1049-1056

Moore JK, Doney SC, Lindsay K (2004) Upper ocean ecosystem dynamics and iron cycling in a global three-dimensional model. Glob Biogeochem Cycles 18, GB4028, doi: 10.1029/2004GB002220

Morel FMM, Hudson RJM, Price NM (1991) Limitation of productivity by trace metals in the sea. Limnol Oceanogr 36:1742-1755

Nakabayashi S, Kuma K, Sasaoka K, Saitoh S, Mochizuki M, Shiga N, Kusakabe M (2002) Variation in iron(III) solubility and iron concentration in the northwestern North Pacific Ocean. Limnol Oceanogr 47:885-892

Palmisano AC, SooHoo JB, SooHoo SL, Kottmeier ST, Craft LL, Sullivan CW (1986) Photoadaptation in Phaeocystis pouchetii advected beneath annual sea ice in McMurdo Sound, Antarctica. J Plankton Res 8:891-906

Raven JA (1990) Predictions of Mn and Fe use efficiencies of phototrophic growth as a function of light availability for growth and $C$ assimilation pathway. New Phytol 116:1-17

Schoemann V, Becquevort S, Stefels J, Rousseau V, Lancelot C (2005) Phaeocystis blooms in the global ocean and their controlling mechanisms: a review. J Sea Res 53:43-66

Sedwick PN, DiTullio GR (1997) Regulation of algal blooms in Antarctic shelf waters by the release of iron from melting sea ice. Geophys Res Lett 24:2515-2518

Sedwick PN, DiTullio GR, Mackey DJ (2000) Iron and manganese in the Ross Sea, Antarctica: seasonal iron limitation in Antarctic shelf waters. J Geophys Res 105: 11321-11336

Sedwick PN, Church TM, Bowie AR, Marsay CM and others (2005) Iron in the Sargasso Sea (Bermuda Atlantic Timeseries Study region) during summer: Eolian imprint, spatiotemporal variability, and ecological implications. Global Biogeochem Cycles 19, GB4006, doi: 10.1029/ 2004GB002445

> Sedwick PN, Garcia NS, Riseman SF, Marsay CM, DiTullio GR (2007) Evidence for high iron requirements of colonial
Phaeocystis antarctica at low irradiance. Biogeochemistry 83:83-97

Shaked Y, Kustka AB, Morel FMM (2005) A general kinetic model for iron acquisition by eukaryotic phytoplankton. Limnol Oceanogr 50:872-882

Smith WO, Gordon LI (1997) Hyperproductivity of the Ross Sea (Antarctica) polynya during austral spring. Geophys Res Lett 24:233-236

Smith WO, van Hilst CM (2004) Effects of assemblage composition on the temporal dynamics of carbon and nitrogen uptake in the Ross Sea. In: DiTullio GR, Dunbar RB (eds) Biogeochemistry of the Ross Sea. Antarctic Research Series, Vol 78. American Geophysical Union, Washington, DC, p 197-208

Smith WO, Codispoti LA, Nelson DM, Manley T, Buskey EJ, Niebauer HJ, Cota GF (1991) Importance of Phaeocystis blooms in the high-latitude ocean carbon cycle. Nature 352:514-516

Smith WO, Marra J, Hiscock MR, Barber RT (2000) The seasonal cycle of phytoplankton biomass and primary productivity in the Ross Sea, Antarctica. Deep-Sea Res II 47 : 3119-3140

> Smith WO, Dinniman MS, Klinck JM, Hofmann E (2003a) Biogeochemical climatologies in the Ross Sea, Antarctica: seasonal patterns of nutrients and biomass. Deep-Sea Res II 50:3083-3101

> Smith WO, Dennet MR, Mathot S, Caron DA (2003b) The temporal dynamics of the flagellated and colonial stages of Phaeocystis antarctica in the Ross Sea. Deep-Sea Res II 50: 605-617

> Stefels J, van Leeuwe MA (1998) Effects of iron and light stress on the biochemical composition of Antarctic Phaeocystis sp. (Prymnesiophyceae). I. Intracellular DMSP concentrations. J Phycol 34:486-495

Sunda W, Huntsman SA (1997) Interrelated influence of iron, light and cell size on marine phytoplankton growth. Nature 390:389-392

Sweeney C (2003) The annual cycle of surface $\mathrm{CO}_{2}$ and $\mathrm{O}_{2}$ in the Ross Sea: a model for gas exchange on the continental shelves of Antarctica. In: DiTullio GR, Dunbar RB (eds) Biogeochemistry of the Ross Sea. Antarctic Research Series, Vol 78. American Geophysical Union, Washington, DC, p 295-312

Sweeney C, Smith WO, Hales B, Bidigare RR and others (2000) Nutrient and carbon removal ratios and fluxes in the Ross Sea, Antarctica. Deep-Sea Res II 47:3395-3421

Tagliabue A, Arrigo KR (2003) Anomalously low zooplankton abundance in the Ross Sea: an alternative explanation. Limnol Oceanogr 48:686-699

Tagliabue A, Arrigo KR (2005) Iron in the Ross Sea: 1. Impact on $\mathrm{CO}_{2}$ fluxes via variation in phytoplankton functional group and non-Redfield stoichiometry. J Geophys Res 110, C03009, doi: 10.1029/2004JC002531

Timmermans KR, Gerringa LJA, De Baar HJW, van der Wagt B, Veldhuis MJW, Croot PL (2001) Growth rates of large and small Southern Ocean diatoms in relation to availability of iron in natural seawater. Limnol Oceanogr 46: 260-266

Timmermans KR, van der Wagt B, de Baar HJW (2004) Growth rates, half-saturation constants, and silicate, nitrate, and phosphate depletion in relation to iron availability of four large, open-ocean diatoms from the Southern Ocean. Limnol Oceanogr 49:2141-2151

> van Hilst CM, Smith WO Jr (2002) Photosynthesis/irradiance relationships in the Ross Sea, Antarctica, and their control by phytoplankton assemblage composition and environmental factors. Mar Ecol Prog Ser 226:1-12 
van Leeuwe MA, Stefels J (1998) Effects of iron and light stress on the biochemical composition of Antarctic Phaeocystis sp. (Prymnesiophyceae). II. Pigment composition. J Phycol 34:496-503

van Leeuwe MA, Stefels J (2007) Photosynthetic responses in Phaeocystis antarctica towards varying light and iron conditions. Biogeochemistry 83:61-70

Worthen DL, Arrigo KR (2003) A coupled ocean-ecosystem

Editorial responsibility: Patricia Glibert,

Cambridge, Maryland, USA model of the Ross Sea. Part 1: Interannual variability of primary production and phytoplankton community structure. In: DiTullio GR, Dunbar RB (eds) Biogeochemistry of the Ross Sea. Antarctic Research Series, Vol 78. American Geophysical Union, Washington, DC, p 93-105

Zivin JA, Waud DR (1982) How to analyze binding, enzyme and uptake data: the simplest case, a single phase. Life Sci 30:1407-1422

Submitted: August 8, 2008; Accepted: June 8, 2009

Proofs received from author(s): September 12, 2009 